Old Dominion University

ODU Digital Commons

OEAS Faculty Publications

Ocean, Earth \& Atmospheric Sciences

2010

\title{
The Widespread Occurrence of Coupled Carbonate Dissolution/Reprecipitation in Surface Sediments on the Bahamas Bank
}

\author{
David J. Burdige \\ Old Dominion University, dburdige@odu.edu
}

Xinping Hu

Richard C.Zimmerman

Old Dominion University, rzimmerm@odu.edu

Follow this and additional works at: https://digitalcommons.odu.edu/oeas_fac_pubs

Part of the Biogeochemistry Commons, and the Oceanography Commons

\section{Repository Citation}

Burdige, David J.; Hu, Xinping; and Zimmerman, Richard C., "The Widespread Occurrence of Coupled Carbonate Dissolution/

Reprecipitation in Surface Sediments on the Bahamas Bank" (2010). OEAS Faculty Publications. 126.

https://digitalcommons.odu.edu/oeas_fac_pubs/126

\section{Original Publication Citation}

Burdige, D.J., Hu, X.P., \& Zimmerman, R.C. (2010). The widespread occurrence of coupled carbonate dissolution/reprecipitation in surface sediments on the Bahamas Bank. American Journal of Science, 310(6), 492-521. doi: 10.2475/06.2010.03

This Article is brought to you for free and open access by the Ocean, Earth \& Atmospheric Sciences at ODU Digital Commons. It has been accepted for inclusion in OEAS Faculty Publications by an authorized administrator of ODU Digital Commons. For more information, please contact

digitalcommons@odu.edu. 


\title{
THE WIDESPREAD OCGURRENGE OF COUPLED CARBONATE DISSOLUTION/REPRECIPITATION IN SURFACE SEDIMENTS ON THE BAHAMAS BANK
}

\author{
DAVID J. BURDIGE ${ }^{* \dagger}$, XINPING HU ${ }^{*}, * *$, and RICHARD C. ZIMMERMAN*
}

\begin{abstract}
Using two complimentary approaches (pore water advection/diffusion/ reaction modeling and stable isotope mass balance calculations) we show that carbonate dissolution/reprecipitation occurs on early diagenetic time scales across a broad range of sediments on the Great Bahamas Bank. The input of oxygen into the sediments, which strongly controls sediment carbonate dissolution, has two major sources-belowground input by seagrasses (that is, seagrass $\mathrm{O}_{2}$ pumping), and permeability-driven advective pore water exchange. The relative importance of these $\mathrm{O}_{2}$ delivery mechanisms depends on both seagrass density, and on how bottom water flow interacts with the seagrass canopy and leads to this advective exchange. Dissolution appears to involve the preferential dissolution of high-Mg calcite, and the rates of dissolution increase linearly with increasing seagrass density. Isotopic evidence of dissolution/reprecipitation is consistent with the occurrence of Ostwald ripening as the mechanism of reprecipitation, in which smaller crystals dissolve and then reprecipitate as larger crystals, with little or no change in mineralogy.

Estimates of the aerially-integrated dissolution flux on the Bahamas Bank suggest that carbonate dissolution is an important loss term in the budget of shallow water carbonate sediments, and that on-bank carbonate dissolution, rather than offshore transport, may represent an important sink for gross shallow water carbonate production. Dissolution in carbonate bank and bay sediments may also be a significant alkalinity source to the surface ocean, and should be considered in global alkalinity/ carbonate budget. Finally, coupled dissolution/reprecipitation may have a major impact on the stable isotope composition of carbonate sediments that are ultimately preserved in the rock record. These processes may therefore need to be considered, for example, when using carbon isotope records to obtain information on the operation of the global carbon cycle during the Phanerozoic.
\end{abstract}

Key words: Bahamas Bank, carbonate dissolution, carbonate reprecipitation, early diagenesis.

INTRODUCTION

Shallow marine environments, including carbonate banks/bays, coral reefs, and tropical and subtropical continental shelves, represent only $\sim 8$ percent of the area of the modern ocean, yet account for $\sim 40$ percent of the global oceanic carbonate production and accumulation (Milliman, 1993). In addition, throughout much of the Phanerozoic shallow water environments were likely even more important sites of carbonate deposition and burial than they are today (Berner, 2004).

The majority of the carbonate produced in modern shallow water settings consists of metastable phases such as aragonite and high-Mg calcite (HMC), which are ultimately transformed into more stable phases such as calcite (or dolomite, under some conditions, for example, Morse and Mackenzie, 1990). These transformations occur across a broad range of time scales, impacting not only the long-term (burial) diagenesis of carbonate sediments (for example, Melim and others, 2002), but also more short-term (early diagenetic) processes occurring in surface (that is, less than $\sim 1$ m) sediments (see recent discussions in Walter and others, 2007). 23529

* Department of Ocean, Earth and Atmospheric Sciences, Old Dominion University, Norfolk, Virginia

** Present address: Department of Marine Sciences, University of Georgia, Athens, Georgia 30602-3636

+ Corresponding author: duburdige@odu.edu; 757 683-4930 
Despite the occurrence of net carbonate accumulation in these environments, carbonate dissolution may occur in carbonate bank sediments as a result of microbial respiration (Walter and Burton, 1990; Walter and others, 1993; Sabine and Mackenzie, 1995; Ku and others, 1999; Burdige and Zimmerman, 2002; Yates and Halley, 2006; Walter and others, 2007; Burdige and others, 2008). The acid required for this dissolution is often metabolic $\mathrm{CO}_{2}$ produced by aerobic respiration. If the organic carbon being remineralized is expressed as $\mathrm{CH}_{2} \mathrm{O}$, then the relevant reactions can be written as follows:

$$
\begin{gathered}
\mathrm{CH}_{2} \mathrm{O}+\mathrm{O}_{2} \rightarrow \mathrm{CO}_{2}+\mathrm{H}_{2} \mathrm{O} \\
\frac{\mathrm{CO}_{2}+\mathrm{CaCO}_{3}+\mathrm{H}_{2} \mathrm{O} \rightarrow \mathrm{Ca}^{2+}+2 \mathrm{HCO}_{3}^{-}}{\mathrm{CH}_{2} \mathrm{O}+\mathrm{O}_{2}+\mathrm{CaCO}_{3} \rightarrow \mathrm{Ca}^{2+}+2 \mathrm{HCO}_{3}^{-}}
\end{gathered}
$$

The $\mathrm{O}_{2}$ needed to drive metabolic carbonate dissolution in these shallow water sediments-as well as carbonate dissolution driven by direct $\mathrm{H}^{+}$production produced during the oxidation of reduced iron and sulfur species ( $\mathrm{Ku}$ and others, 1999) appears to have two primary sources: belowground input of photosyntheticallyproduced $\mathrm{O}_{2}$ from seagrass roots and rhizomes (sometimes referred to as seagrass $\mathrm{O}_{2}$ "pumping"), plus pore water advective exchange in these high permeability sediments (Burdige and others, 2008).

In many shallow water settings the observed sediment carbonate dissolution actually appears to represent net dissolution, that is, the balance between gross dissolution and reprecipitation (Patterson and Walter, 1994; Hu and Burdige, 2007, 2008; Walter and others, 2007). The thermodynamic (or solubility) driving force for this coupled process is, however, not well understood (see the Pore Water Evidence for Coupled Dissolution/Reprecipitation section for details). Past geochemical studies of dissolution/reprecipitation have tended to focus on more organic-"rich" carbonate sediments (also see Rude and Aller, 1991; Walter and others, 1993; Ku and others, 1999) that are not necessarily representative of the more organic-"poor" sediments generally found on shallow water carbonate platforms. At the same time, carbonate dissolution and reprecipitation have been discussed in the carbonate sedimentology literature in terms of the formation of micrite and carbonate cements (Purdy, 1968; Bathurst, 1974; Reid and Macintyre, 2000), although the topic "has long been a subject of controversy and semantic discussion" (Reid and Macintyre, 1998). Furthermore, many of these studies have been largely descriptive in nature, focusing on the mineralogy, morphology and distribution of micrites and carbonate cements.

Given these observations, in this paper we will use two complimentary approaches to demonstrate the widespread occurrence of carbonate dissolution/reprecipitation in sediments on the Bahamas Bank. This work builds on our previous studies of these processes at a limited number of sites on the Bank (Hu and Burdige, 2007, 2008; Burdige and others, 2008). One of the approaches we used is based on a pore water stable isotope mass balance while the other uses an advection/diffusion/reaction model applied to pore water solute concentration profiles. With these results we will show that dissolution/reprecipitation is an important part of the early diagenesis of Bahamas Bank sediments in general, and we will discuss the factors controlling this coupled process. Finally, we will use these results to further examine the geologic and geochemical significance of coupled carbonate dissolution/reprecipitation.

MATERIALS AND METHODS

Study Sites

The work described here was carried out at sites on the Great Bahamas Bank in March, 2004 using the R/V F. G. Walton Smith as the sampling platform (fig. 1 and 


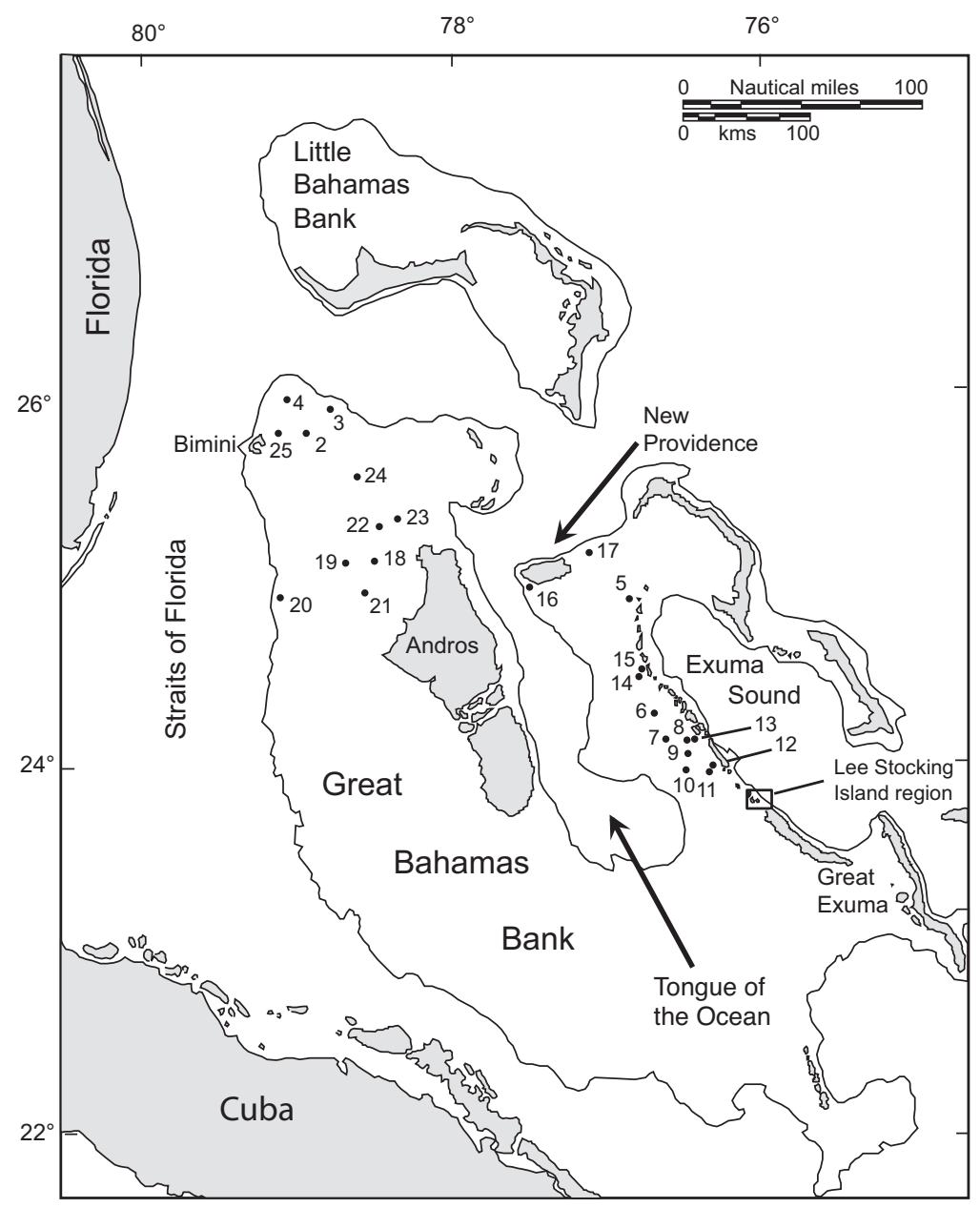

Fig. 1. A map of the Bahamas Bank showing the sites occupied in this study (map modified after Bathurst, 1974). Also shown here is the Lee Stocking Island region.

table 1). Water depths at these sites ranged from 4 to $10 \mathrm{~m}$ (average depth $\sim 6 \mathrm{~m}$ ). Visual inspection of the sediments at these sites showed that they ranged from fine-grained carbonate muds and pellet muds on the west side of Andros Island, to more coarse-grained oolitic carbonate sands and grapestones on the northern part of the Bank and on the eastern arm of the Bank along the Exuma Cays ( $\mathrm{F}$. Neuweiler, personal communication). Many of the sites were inhabited by seagrasses, with Thalassia testudinum (turtle grass) dominating at all of the seagrasscontaining sites except sites 3 and 25, where Syringodium filiforme (manatee grass) was also observed in significant densities (Bodensteiner, ms, 2006).

The dominant mineralogy of these sediments (based on X-ray diffraction analyses) was aragonite $(\sim 80-90 \%)$ and high-Mg calcite (HMC; $\sim 10-20 \%)$, the latter with a Mg-content of $\sim 12$ mole percent ( $\mathrm{Hu}, \mathrm{ms}, 2007$; $\mathrm{Hu}$ and Burdige, 2008). This mineralogy is consistent with past studies of Bahamas Bank sediments (Morse and others, 1985; Swart and others, 2009), including the sediments we have studied previously around Lee Stocking Island, in the southern portion of the Exuma Cays (fig. 
TABLE 1

Sampling sites and their description

\begin{tabular}{lccclc}
\hline Site & Location & $\begin{array}{c}\text { Water } \\
\text { depth }(\mathrm{m})\end{array}$ & $\begin{array}{c}\text { Grain size } \\
(\text { mean; } \mu \mathrm{m})^{*}\end{array}$ & \multicolumn{1}{c}{ Sediment Description } & $\begin{array}{c}\text { Seagrass LAI } \\
\left(\mathrm{m}^{2} / \mathrm{m}^{2}\right)\end{array}$ \\
\hline \hline 2 & $25^{\circ} 47.54^{\prime} \mathrm{N}, 78^{\circ} 55.60^{\prime} \mathrm{W}$ & 6.0 & 409 & Ooid sand & $0.96 \pm 0.04$ \\
3 & $25^{\circ} 51.05^{\prime} \mathrm{N}, 78^{\circ} 43.90^{\prime} \mathrm{W}$ & 10.5 & 238 & Pellet mud & $1.48 \pm 0.10$ \\
4 & $25^{\circ} 58.65^{\prime} \mathrm{N}, 79^{\circ} 4.39^{\prime} \mathrm{W}$ & 9.5 & 587 & Coarse ooids & $2.24 \pm 0.08$ \\
5 & $24^{\circ} 48.68^{\prime} \mathrm{N}, 76^{\circ} 50.02^{\prime} \mathrm{W}$ & 5.6 & 1201 & Grapestone/ooid & $0.03 \pm 0.02$ \\
6 & $24^{\circ} 21.44^{\prime} \mathrm{N}, 76^{\circ} 46.30^{\prime} \mathrm{W}$ & 7.9 & 691 & Grapestone/ ooid & 0 \\
8 & $24^{\circ} 13.87^{\prime} \mathrm{N}, 76^{\circ} 31.23^{\prime} \mathrm{W}$ & 5.0 & 521 & Grapestone/cryptocrystalline mud & $0.25 \pm 0.04$ \\
9 & $24^{\circ} 7.29^{\prime} \mathrm{N}, 76^{\circ} 32.34^{\prime} \mathrm{W}$ & 5.2 & 678 & Pellet grapestone sand & 0 \\
10 & $23^{\circ} 5.34^{\prime} \mathrm{N}, 76^{\circ} 32.72^{\prime} \mathrm{W}$ & 5.7 & 1319 & Pellet grapestone sand & $0.02 \pm 0.00$ \\
11 & $23^{\circ} 56.24^{\prime} \mathrm{N}, 76^{\circ} 23.83^{\prime} \mathrm{W}$ & 5.6 & 374 & Pellet grapestone/fine grain sand & $0.09 \pm 0.01$ \\
12 & $23^{\circ} 56.37^{\prime} \mathrm{N}, 76^{\circ} 23.76^{\prime} \mathrm{W}$ & 5.3 & 272 & Pellet mud & $1.96 \pm 0.07$ \\
13 & $24^{\circ} 14.03^{\prime} \mathrm{N}, 76^{\circ} 30.20^{\prime} \mathrm{W}$ & 4.2 & 406 & Ooid sand & $0.75 \pm 0.05$ \\
14 & $24^{\circ} 34.91^{\prime} \mathrm{N}, 76^{\circ} 49.81^{\prime} \mathrm{W}$ & 5.5 & 558 & Ooid sand & $0.57 \pm 0.02$ \\
15 & $24^{\circ} 35.08^{\prime} \mathrm{N}, 76^{\circ} 48.98^{\prime} \mathrm{W}$ & 3.7 & 340 & Pellet sand/ooid/grapestone & $1.20 \pm 0.05$ \\
16 & $24^{\circ} 59.30^{\prime} \mathrm{N}, 77^{\circ} 29.93^{\prime} \mathrm{W}$ & 5.6 & 940 & Coarse sand & $0.01 \pm 0.00$ \\
17 & $25^{\circ} 4.34^{\prime} \mathrm{N}, 77^{\circ} 4.33^{\prime} \mathrm{W}$ & 7.5 & 406 & Ooid sand & $0.47 \pm 0.02$ \\
18 & $25^{\circ} 7.03^{\prime} \mathrm{N}, 78^{\circ} 28.42^{\prime} \mathrm{W}$ & 4.9 & 458 & Pellet mud & $0.24 \pm 0.02$ \\
20 & $24^{\circ} 55.92^{\prime} \mathrm{N}, 79^{\circ} 4.46^{\prime} \mathrm{W}$ & 6.7 & 423 & Ooid/grapestone & $1.08 \pm 0.05$ \\
21 & $24^{\circ} 56.62^{\prime} \mathrm{N}, 78^{\circ} 30.54^{\prime} \mathrm{W}$ & 5.4 & 306 & Pellet mud & $0.10 \pm 0.01$ \\
24 & $25^{\circ} 36.03^{\prime} \mathrm{N}, 78^{\circ} 36.96^{\prime} \mathrm{W}$ & 6.2 & 503 & Ooid/grapestone & $0.35 \pm 0.02$ \\
25 & $25^{\circ} 48.41^{\prime} \mathrm{N}, 79^{\circ} 6.81^{\prime} \mathrm{W}$ & 5.4 & 425 & Ooid sand & $3.73 \pm 0.40$ \\
\hline
\end{tabular}

* Complete grain size results are presented in $\mathrm{Hu}(\mathrm{ms}, 2007)$.

1; Burdige and Zimmerman, 2002; Burdige and others, 2008). Also note that as a part of the analysis of the results presented here we will incorporate (as appropriate) results from our previous studies of these sediments. Although we did not measure total organic carbon in the sediments of this study, concentrations in similar sediments on the Bahamas Bank are less than $~ 0.5$ weight percent (Morse and others, 1985; Burdige and Zimmerman, 2002).

\section{Sample Collection and Analytical Methods}

Pore water samples were collected in situ by divers, using pore water sippers designed for use in sandy sediments (Burdige and Zimmerman, 2002; Hu and Burdige, 2007). A bottom water sample and three sets of pore water profiles were collected at each site, down to a sediment depth of $20 \mathrm{~cm}$. After pore waters were collected and returned to the ship, the samples were equilibrated at lab temperature for 30 minutes, and $\mathrm{O}_{2}$ concentrations were measured on an aliquot of the water using an oxygen optode (FOXY-18G, Ocean Optics ${ }^{\circledR}$ ) connected to an Ocean Optics SF2000 spectrophotometer (Hu, ms, 2007; Burdige and others, 2008). The remaining pore water was filtered through a $0.45 \mu \mathrm{m}$ nylon disc filter and preserved in appropriate storage vessels at $4^{\circ} \mathrm{C}$ for further analyses (Burdige and others, 2008).

Titration alkalinity $\left(\mathrm{A}_{\mathrm{T}}\right)$ was determined on board the ship by automated Gran titration using certified $\mathrm{HCl}$ and Scripps Reference Seawater as an external standard (Dickson and others, 2003). pH (NBS) and total dissolved sulfide (Cline, 1969) were also analyzed on board the ship. $\mathrm{A}_{\mathrm{T}}$ and $\mathrm{pH}$ were analyzed in all three sets of pore water samples from each site, while sulfide was determined in one set. At ODU, DIC was analyzed with a UIC 5011 coulometer (Dickson and others, 2007) using Scripps Reference Seawater as the reference material. The $\delta^{13} \mathrm{C}$ of the pore water DIC was determined at ODU as described in Hu and Burdige (2007) using a PDZ Europa ${ }^{\circledR}$ GEO 20-20 isotopic ratio mass spectrometer (IRMS). 
Pore water $\mathrm{Ca}^{2+}$ concentrations were determined by automated titration, using EGTA as the titrant and a Thermo-Orion calcium ion selective electrode (ISE) to detect the end-point. Pore water chloride concentrations were determined by automated titration using $\mathrm{AgNO}_{3}$ as the titrant and a Brinkman $\mathrm{Ag}$ Titrode ${ }^{\mathrm{TM}}$ for end-point detection. Sulfate was analyzed by ion chromatography. IAPSO standard seawater (salinity 34.996) was used to standardize both titrants (EGTA and $\mathrm{AgNO}_{3}$ ) as well as to construct sulfate standard curves (Burdige and others, 2008).

At selected sites, seagrass (turtle grass and manatee grass), calcareous macroalgae (Penicillus sp., Rhipocelaphus sp., and Udotea sp.), and sediment samples were collected by divers, frozen, and returned to ODU. All of these samples were processed back at ODU, with seagrasses and macroalgae analyzed for $\delta^{13} \mathrm{C}$ at ODU and sediments analyzed for $\delta^{13} \mathrm{C}$ at the UC Davis Stable Isotope Lab (Hu and Burdige, 2007). At ODU $\delta^{13} \mathrm{C}$ values were calculated relative to PDB, while at UC Davis they were calculated relative to V-PDB. Since the difference between V-PDB and PDB is negligibly small (Mook and De Vries, 2001), the complete isotope data set is internally consistent.

Surface sediments were wet-sieved for grain size analysis (Barth, 1984) using sieve sizes of $2000 \mu \mathrm{m}, 600 \mu \mathrm{m}, 125 \mu \mathrm{m}$, and $63 \mu \mathrm{m}$. Mean grain size $(d)$ was calculated using the equation $d=\sum f_{n} d_{n}$, where $f_{n}$ is the weight percent of a size fraction, and $d_{n}$ is the median grain size in that fraction. For the $>2000 \mu \mathrm{m}$ and $<63 \mu \mathrm{m}$ size fractions, median grain sizes of $2250 \mu \mathrm{m}$ and $31.5 \mu \mathrm{m}$ were assumed (D. Swift, personal communication).

The uncertainties of all analyses were: $\mathrm{O}_{2}, \pm 3 \%$; alkalinity, $\pm 2 \%$; DIC, $\pm 2 \%$; $\mathrm{pH}$, $\pm 0.02 \mathrm{pH}$ units; $\mathrm{Ca}^{2+}, \pm 1 \% ; \mathrm{Cl}^{-}, \pm 0.2 \%, \delta^{13} \mathrm{C}$ (DIC, organic carbon, and carbonate carbon), $\pm 0.2 \% \circ, \pm 0.1 \%$, and $\pm 0.04 \%$; sulfate, $\pm 3 \%$; sulfide, $\pm 2 \%$.

Seagrass density at the sites was quantified as leaf area index $(L A I)$, defined as $\mathrm{m}^{2}$ one-sided leaf area per $\mathrm{m}^{2}$ seafloor $\left(\mathrm{m}_{\text {leaf }}^{2} \cdot \mathrm{m}_{\text {seafloor }}^{-2}\right) . L A I$ was determined as described elsewhere (Burdige and Zimmerman, 2002; Bodensteiner, ms, 2006).

The species distribution of DIC (carbonate, bicarbonate, aqueous $\mathrm{CO}_{2}$ ) in pore waters and bottom waters was calculated using the program CO2SYS (Lewis and Wallace, 1998) and our $\mathrm{pH}$ and DIC data. Calculated values of $\mathrm{A}_{\mathrm{T}}$ using this approach agreed to within $0.5 \%( \pm 4.5 \%)$ of measured values of $\mathrm{A}_{T}(\mathrm{n}=633$ alkalinity determinations).

\section{RESULTS}

\section{Pore Water Results}

Depth profiles of pore water solutes, DIC $\delta^{13} \mathrm{C}$, and aragonite saturation index $\left(\Omega_{\text {arag }}\right)$, at selected sites on the Bahamas Bank are shown in figures 2,3 , and 4 . In general, $\mathrm{O}_{2}$ concentration and $\mathrm{pH}$ decreased with sediment depth, accompanied by increases in $\mathrm{A}_{\mathrm{T}}$, DIC, and $\mathrm{Ca}^{2+}$. Such profiles are consistent with the occurrence of metabolic carbonate dissolution.

At the same time, the relatively flat concentrations gradients in the upper $\sim 1$ to 2 $\mathrm{cm}$ of sediment (that is, no significant concentration changes in this region) are likely due to pore water advective exchange between the bottom waters and these high permeability sediments. The calculated permeability of these sediments ranged from $\sim 2-40 \times 10^{-10} \mathrm{~m}^{2}$ ( $\mathrm{Hu}, \mathrm{ms}, 2007$ ), and in sediments where the permeability exceeds $\sim 10^{-12} \mathrm{~m}^{2}$ advective transport of this fashion is thought to be significant down to sediment depths of at least several centimeters (Huettel and Webster, 2001). The occurrence of this advection also requires a near seabed pressure gradient, which can be generated by wave action (oscillating bottom currents). It can also be generated by bottom water flow over surface topography (for example, sand ripples or physical surface roughness), biogenic structures such as animal mounds, or submerged seagrass canopies (Boudreau and others, 2001; Koch and others, 2006). 


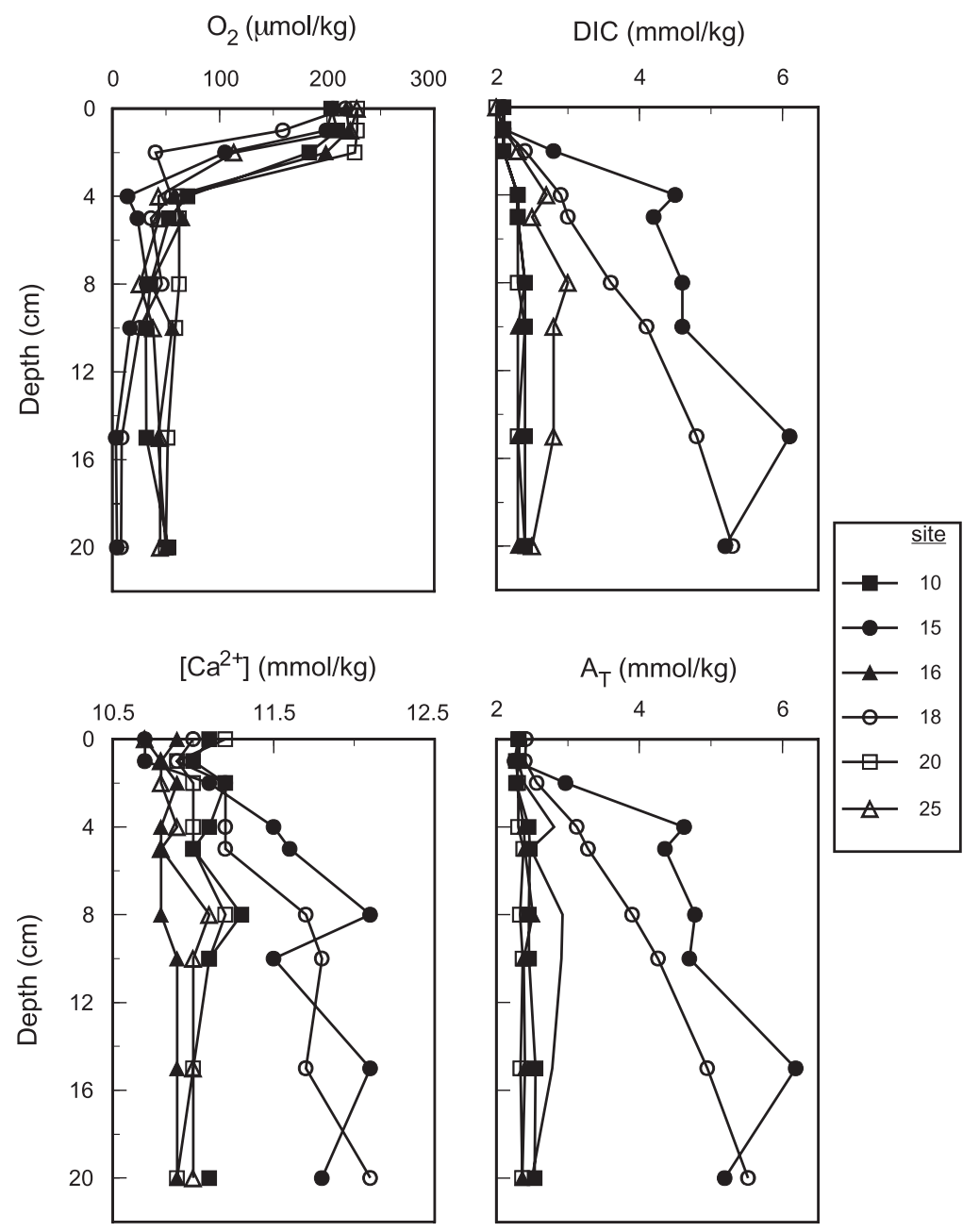

Fig. 2. Pore water depth profiles of dissolved oxygen, dissolved inorganic carbon (DIC), $\mathrm{Ca}^{2+}$ and total alkalinity $\left(\mathrm{A}_{\mathrm{T}}\right)$ at selected sites on the Bahamas Bank. The values shown here represent average values from 3 replicate sippers collected at each site.

Increases with sediment depth in pore water $\mathrm{A}_{\mathrm{T}}$, DIC, and $\mathrm{Ca}^{2+}$ concentrations were highly correlated, as indicated by the strong linear relationship between $\Delta \mathrm{A}_{\mathrm{T}}$ and $\Delta \mathrm{DIC}$ at these sites (fig. 5A). The slope of the best-fit line through these data (1.03 \pm $0.01)$ is consistent with equations (1-3). Similar property-property plots of $\Delta \mathrm{Ca}^{2+}$ versus either $\Delta \mathrm{DIC}$ (fig. $5 \mathrm{~B}$ ) or $\Delta \mathrm{A}_{\mathrm{T}}$ (not shown here) showed greater scatter, although the correlations were still significant $(\mathrm{Hu}, \mathrm{ms}, 2007)$. The slopes of these lines are $\sim 0.3$ (versus the value of 0.5 predicted by equation 3 ). The significance of this observation will be discussed in the General Observations section.

Pore water sulfate profiles did not show any appreciable downcore gradients with depth (fig. 3). For the entire set of pore water samples in this study $(n=176)$, the average value of $\Delta\left[\mathrm{SO}_{4}^{2-}\right]$ was $-0.36 \pm 0.06 \mathrm{mmol} \cdot \mathrm{kg}^{-1}$, which is smaller than the analytical uncertainty of the sulfate measurement. Pore water sulfide levels were generally low, with 11 out of 21 stations having total dissolved sulfide $\left(\mathrm{\Sigma H}_{2} \mathrm{~S}\right)$ concen- 

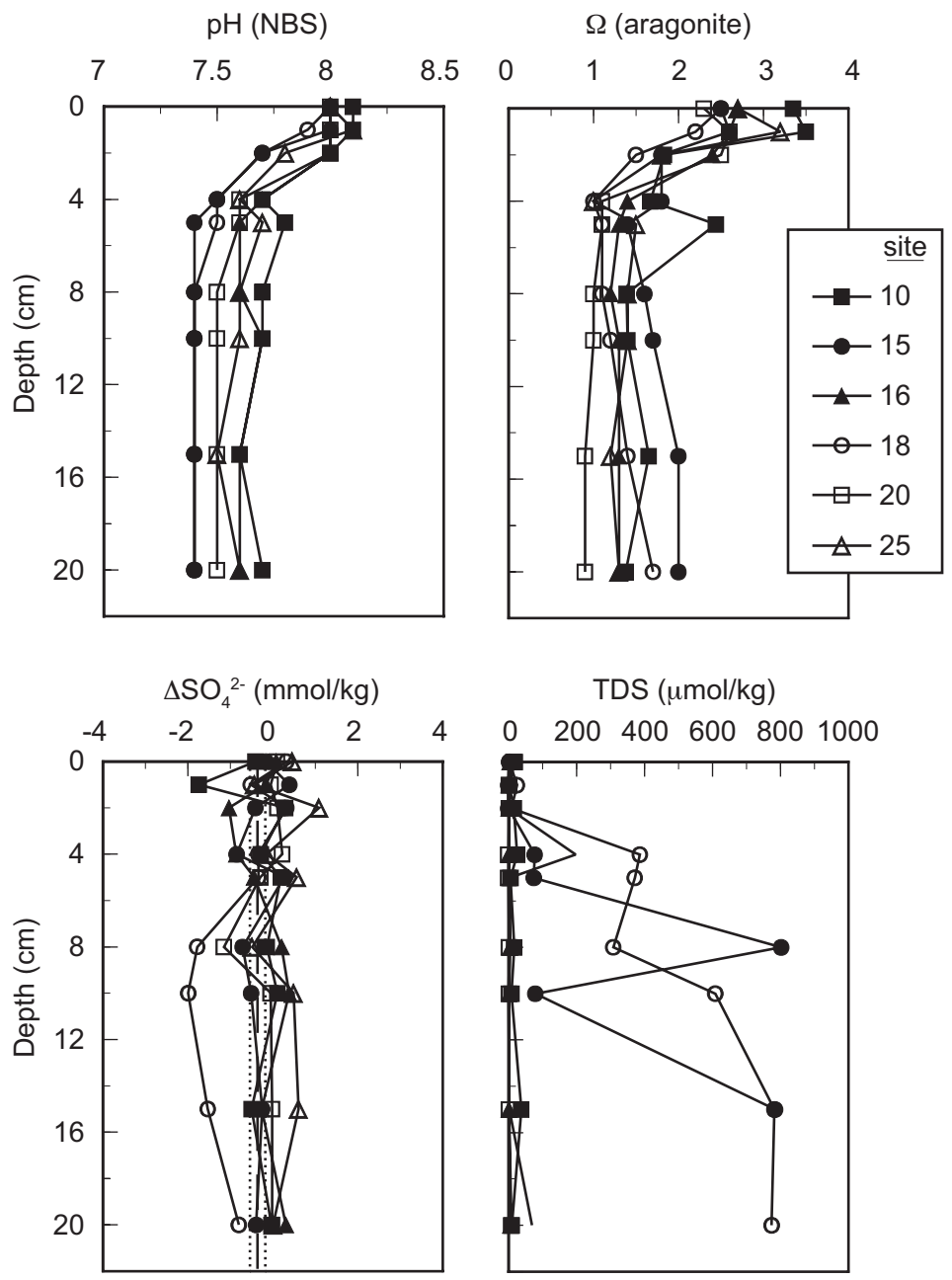

Fig. 3. Pore water depth profiles of $\mathrm{pH}$, the saturation state with respect to aragonite [ $\Omega$ (aragonite)], $\Delta \mathrm{SO}_{4}^{2-}$, and total dissolved sulfide $\left(\Sigma \mathrm{H}_{2} \mathrm{~S}\right)$, all at selected sites on the Bahamas Bank. The values shown here represent average values from 3 replicate sippers collected at each site. $\Omega$ (aragonite) was calculated as described in $\mathrm{Hu}$ and Burdige (2008). $\Delta \mathrm{SO}_{4}^{2-}$ is the change in the pore water sulfate concentration relative to the bottom water value, normalized for any changes in total salinity with depth in the pore waters (Burdige and Zimmerman, 2002). This salinity normalization has little effect on the calculations here since the relative difference between pore water and bottom water salinities in these sediments averaged $\sim 0.4$ for an average bottom water salinity of $\sim 37$ (range: $36.3-38.2$ ).

trations below $0.1 \mathrm{mmol} \cdot \mathrm{kg}^{-1}$. At only 4 sites $(13,14,15$, and 18) did sulfide levels increase significantly and consistently with depth, to concentrations ranging from 1.1 to $1.6 \mathrm{mmol} \cdot \mathrm{kg}^{-1}$. A comparison of the $\Sigma \mathrm{H}_{2} \mathrm{~S}$ and $\mathrm{O}_{2}$ profiles suggested that virtually all sulfide was internally recycled (that is, oxidized back to sulfate). Thus, little or no net sulfate reduction occurred in the upper $20 \mathrm{~cm}$ of these sediments, consistent with the $\Delta\left[\mathrm{SO}_{4}^{2-}\right]$ results discussed above, and with our previous findings in Lee Stocking Island sediments (Hu and Burdige, 2007; Burdige and others, 2008).

pH and pore water saturation state.-Pore water $\mathrm{pH}$ generally decreased with depth below the sediment-water interface with the steepest gradients in the upper $5 \mathrm{~cm}$ (fig. 3 ). Deeper in the sediments, the $\mathrm{pH}$ values were relatively constant at $\sim 7.3$ to 7.7 . 


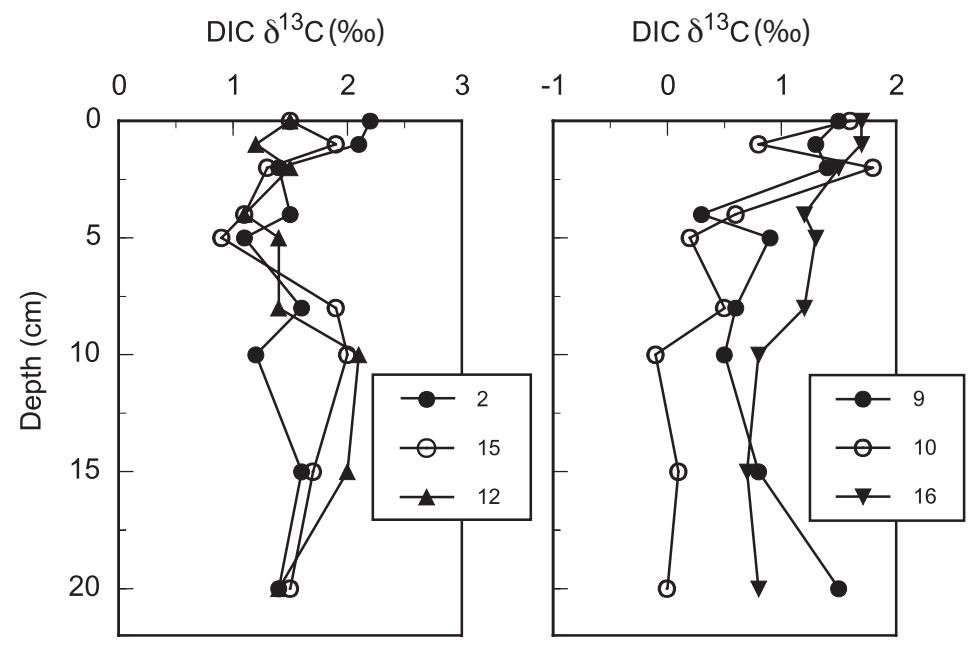

Fig. 4. Pore water depth profiles of $\delta^{13} \mathrm{C}$ of the pore water DIC at selected sites on the Bahamas Bank. Note the two distinct general trends in the data that are shown in each panel (see the text for details).

Consistent with these $\mathrm{pH}$ changes were changes with depth in carbonate mineral saturation state. While the bottom waters were supersaturated with respect to all carbonate mineral phases, the pore waters approached saturation with respect to aragonite below $\sim 4 \mathrm{~cm}$ (figs. 3 and 6 ) but generally remained supersaturated. These trends are similar to those observed by Morse and others (1985) in their studies of Bahamas Bank sediments.

With depth, the Bahamas Bank sediment pore waters we studied also approached saturation with respect to high-Mg calcite (13 mole\% HMC). However, when considering this observation, it is important to note that there is a fair degree of uncertainty, in
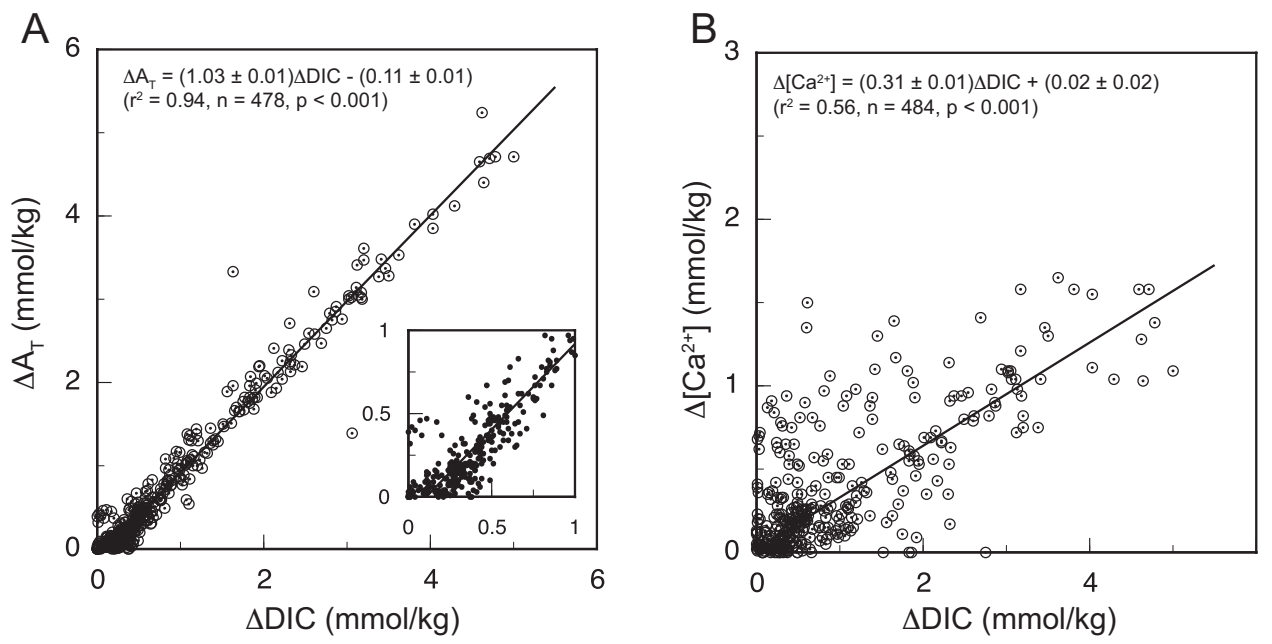

Fig. 5. Scatter plots of $\Delta \mathrm{A}_{\mathrm{T}}$ versus $\Delta \mathrm{DIC}$ and $\Delta\left[\mathrm{Ca}^{2+}\right]$ versus $\Delta \mathrm{DIC}$ for pore water samples collected at sites on the Bahamas Bank (" $\Delta$ " concentrations are pore water minus bottom water concentrations). The insert in the left panel more clearly illustrates the positive x-intercept of this scatter plot. 


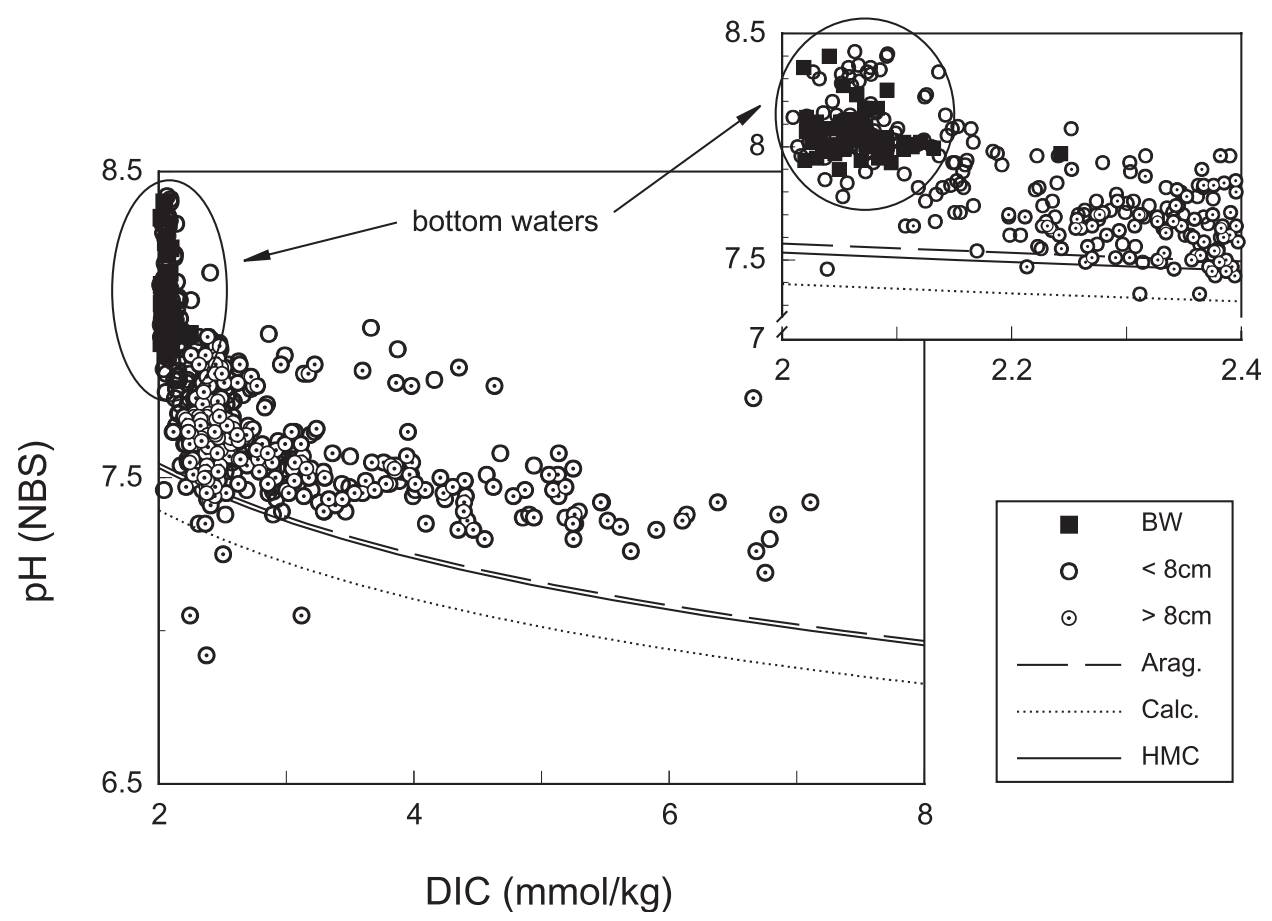

Fig. 6. A scatter plot of pore water and bottom water $\mathrm{pH}$ values and DIC concentrations for sites on the Bahamas Bank. Also shown are the solubility lines for calcite and aragonite (based on apparent solubility constants in Mucci, 1983), and for 13 mole\% HMC. The HMC solubility line was based on the "best-fit" line for biogenic HMC solubility versus mole \% Mg (Morse and Mackenzie, 1990; Morse and others, 2006). This plot was constructed as discussed in Morse and others (1985); additional details can be found in $\mathrm{Hu}$ (ms, 2007).

general, in the solubility of HMC (see discussions in Morse and Mackenzie, 1990; Morse and others, 2006). The solubility of HMC is also a function of its Mg-content, with the solubility increasing by $\sim 0.1 \log$ IAP units (roughly 25\%) as the Mg-content increases from 5 mole percent to 15 mole percent.

\section{Pore Water Modeling}

Rates of sediment processes were estimated by fitting $\mathrm{O}_{2}$, DIC, $\mathrm{A}_{\mathrm{T}}$ and $\mathrm{Ca}^{2+}$ pore water profiles with a recently described advection-diffusion-reaction (ADR) model (Burdige and others, 2008). The model considers the following processes that affect these solutes: diffusive transport in the sediments; depth-dependent $\mathrm{O}_{2}$ input through seagrass roots and rhizomes (Bodensteiner, ms, 2006); advective pore water exchange in these permeable sediments; and solute production $\left(\mathrm{A}_{\mathrm{T}}\right.$, DIC and $\left.\mathrm{Ca}^{2+}\right)$ or consumption $\left(\mathrm{O}_{2}\right)$ associated with metabolic carbonate dissolution (eqs 1-3). Advective pore water exchange is parameterized in the model as a non-local exchange process with an exchange constant that decreases exponentially with depth, that is, advection is given by $\alpha_{z}\left(C_{z}-C_{o}\right)$ where $C_{\mathrm{z}}$ is the pore water concentration at depth $z, C_{\mathrm{o}}$ is the bottom water concentration, and $\alpha_{\mathrm{z}}$, the non-local exchange coefficient, is given by $\alpha_{o} e^{-\beta z}$. In our earlier work (Burdige and others, 2008) we showed that the integrated belowground input of $\mathrm{O}_{2}$ by seagrasses at a given site was proportional to the leaf area index $(L A I)$ of the site, and we assumed that this input was distributed through the upper $20 \mathrm{~cm}$ of sediment based on the relative belowground distribution of seagrass root and rhizome biomass. 
TABLE 2

Reaction rates calculated using the ADR model (units: $\mathrm{mmol} / \mathrm{m}^{2} / \mathrm{d}$ )*

\begin{tabular}{lccccccl}
\hline Site & LAI & DIRO & DIRA & DIRD & DIRC & \multicolumn{2}{c}{$R_{\mathrm{CD}}{ }^{* *}$} \\
\hline \hline 2 & $0.96 \pm 0.04$ & 12.5 & 26.3 & 24.0 & 6.9 & $12.1 \pm 1.0$ & $(8.2 \%)$ \\
3 & $1.48 \pm 0.10$ & 42.8 & 80.5 & 85.9 & 31.7 & $42.9 \pm 2.2$ & $(5.1 \%)$ \\
4 & $2.24 \pm 0.08$ & 76.1 & 152.2 & 152.2 & 82.6 & $76.1 \pm 0.0$ & $(0 \%)$ \\
5 & $0.03 \pm 0.02$ & 3.2 & 3.5 & 6.4 & 2.7 & $3.2 \pm 1.2$ & $(37.2 \%)$ \\
6 & 0 & 0.02 & 0.1 & 0.05 & 0.03 & $0.02 \pm 0.02$ & $(102 \%)$ \\
8 & $0.25 \pm 0.04$ & 3.7 & 7.3 & 7.6 & 2.2 & $3.8 \pm 0.2$ & $(4.1 \%)$ \\
9 & 0 & 6.5 & 13.0 & 13.2 & & $6.6 \pm 0.1$ & $(1.1 \%)$ \\
10 & $0.02 \pm 0.00$ & 1.4 & 2.8 & 2.9 & 0.1 & $1.4 \pm 0.0$ & $(0.4 \%)$ \\
11 & $0.09 \pm 0.01$ & 2.0 & 4.1 & 4.1 & 30.2 & $2.0 \pm 0.0$ & $(0.8 \%)$ \\
12 & $1.96 \pm 0.07$ & 29.3 & 58.7 & 58.8 & 61.1 & $29.4 \pm 0.1$ & $(0.2 \%)$ \\
13 & $0.75 \pm 0.05$ & 10.2 & 20.3 & 20.7 & 7.2 & $10.3 \pm 0.2$ & $(1.8 \%)$ \\
14 & $0.57 \pm 0.02$ & 7.4 & 14.7 & 15.1 & 6.1 & $7.5 \pm 0.1$ & $(2.0 \%)$ \\
15 & $1.20 \pm 0.05$ & 14.7 & 29.0 & 30.1 & 10.3 & $15.0 \pm 0.5$ & $(3.4 \%)$ \\
16 & $0.01 \pm 0.00$ & nc & nc & nc & nc & & \\
17 & $0.47 \pm 0.02$ & nc & nc & nc & nc & & \\
18 & $0.24 \pm 0.02$ & 3.4 & 6.6 & 6.9 & 2.1 & $3.4 \pm 0.1$ & $(3.9 \%)$ \\
20 & $1.08 \pm 0.05$ & nc & nc & nc & nc & & \\
21 & $0.10 \pm 0.01$ & 1.6 & 3.3 & 3.1 & 0.9 & $1.6 \pm 0.1$ & $(4.4 \%)$ \\
24 & $0.35 \pm 0.02$ & 22.2 & 44.3 & 44.4 & 11.1 & $22.2 \pm 0.0$ & $(0 \%)$ \\
25 & $3.73 \pm 0.40$ & 80.1 & 159.8 & 161.0 & 56.7 & $80.4 \pm 0.5$ & $(0.6 \%)$ \\
\hline
\end{tabular}

* DIRO, DIRA, DIRD, and DIRC = depth-integrated rates of (respectively) oxygen consumption, alkalinity production, DIC production and $\mathrm{Ca}^{2+}$ production. $R_{\mathrm{CD}}=$ depth-integrated rate of carbonate dissolution (estimated as described in note $* *$ ).

$\mathrm{nc}=$ the model did not converge for the data from these sites $(16,17$, and 20; see $\mathrm{Hu}, 2007$, for details).

** The value of $R_{\mathrm{CD}}$ can be shown to be equivalent to any of these four quantities: DIRO, DIRA/2, DIRD/2, DIRD $-0.5 \cdot$ DIRA (see discussions in Burdige and others, 2008, for details). Shown here is the average of these values $\left( \pm\right.$ std. dev.), and the value in parentheses to the left of the average value of $R_{\mathrm{CD}}$ is its relative standard deviation.

With the approach used here, the ADR equation for each solute is "inverted" so that depth distributions of solute production $\left(\mathrm{A}_{\mathrm{T}}, \mathrm{DIC}\right.$ and $\left.\mathrm{Ca}^{2+}\right)$ or consumption $\left(\mathrm{O}_{2}\right)$ are defined by the known pore water data and sediment $L A I$ values, and the unknown parameters $\alpha_{\mathrm{o}}$ and $\beta$. The same is then also true for the depth-integrated rates of $\mathrm{A}_{\mathrm{T}}, \mathrm{DIC}$ and $\mathrm{Ca}^{2+}$ production (DIRA, DIRD, and DIRC) and $\mathrm{O}_{2}$ consumption (DIRO), which then implies that these four depth-integrated rates can be viewed as "functions" of $\alpha_{\text {o }}$ and $\beta$. These advection parameters are then used to fit the data to the model by assuming that they must predict depth-integrated rates of solute production or consumption that are consistent with the stoichiometry of equation (3), that is, 2 . $D I R O=D I R D, 2 \cdot D I R O=D I R A$, and DIRD $=D I R A$. This approach, along with the error minimization procedure used to determine the best-fit values of $\alpha_{0}$ and $\beta$, are described in Burdige and others (2008) and $\mathrm{Hu}$ (ms, 2007).

The results of this fitting procedure are listed in table 2. Also included here are depth-integrated rates of sediment carbonate dissolution $\left(R_{\mathrm{CD}}\right)$ determined from the individual solute production/consumption rates. All of these rates, including values of $R_{\mathrm{CD}}$, agree well with other estimates in the literature (Andersson and others, 2007; Burdige and others, 2008; $\mathrm{Hu}$ and Burdige, 2008). As we have observed previously for Lee Stocking Island sediments alone (Burdige and others, 2008), values of $R_{\mathrm{CD}}$ increase with increasing seagrass density (fig. 7).

We have specifically chosen here as in Burdige and others (2008) to not use DIRC, the model-derived depth-integrated rates of pore water $\mathrm{Ca}^{2+}$ production, in the mass 


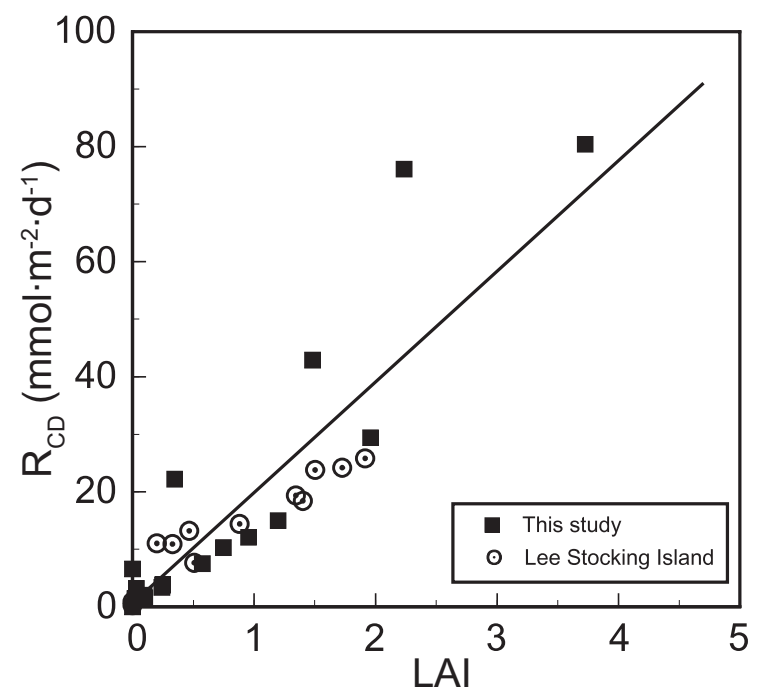

Fig. 7. The depth-integrated rate of sediment carbonate dissolution $\left(R_{\mathrm{CD}}\right)$ versus $L A I$ (leaf area index) for Bahamas Bank sediments (data from table 2 and Burdige and others, 2008). The best-fit line through these data is $R_{\mathrm{CD}}=(19.9 \pm 2.0) \cdot L A I+(0.2 \pm 2.4)\left[\mathrm{n}=29 ; \mathrm{r}^{2}=0.79, \mathrm{p}<0.001\right]$.

balance fitting procedure described above. We have taken this approach since to do so would require information that is currently unknown, or subject to some uncertainty, including knowledge of the specific carbonate phase undergoing dissolution (for example, aragonite versus high-Mg calcite) and, more importantly, its $\mathrm{Mg}$ (versus Ca) content. It also requires that the model take into account the possible occurrence of carbonate reprecipitation in conjunction with carbonate dissolution, and the (poorlyconstrained) composition (that is, Mg-content) of any secondary carbonate that forms by reprecipitation (see discussions in Burdige and others, 2008, and references cited therein for further details). However the values of DIRC calculated above can be used with the other model results to provide information on some of these unknowns. In particular, we note that there is a strong co-variance between DIRC and $R_{\mathrm{CD}}$ (fig. 8), which will be discussed in the Pore Water Evidence for Coupled Dissolution/Reprecipitation section in further detail.

\section{$\delta^{13}$ C Results}

$\delta^{13} C$ of the sediment organic matter sources and carbonate sediments. - At the eight sites where seagrass samples were collected, Thalassia testudinum had $\delta^{13} \mathrm{C}$ values that ranged from -4.9 to -9.7 permil. At the two sites where Syringodium filiforme was observed, this seagrass had $\delta^{13} \mathrm{C}$ values that ranged from -6.0 to -7.7 permil (table 3 ). These values agreed with other values reported in the literature for these seagrasses growing in similar environments (Hemminga and Mateo, 1996; Fourqurean and others, 2005). However, the seagrasses we sampled were relatively enriched in ${ }^{13} \mathrm{C}$ as compared to phytoplankton in the surrounding Atlantic Ocean, which have $\delta^{13} \mathrm{C}$ values of ca. - 21 permil (Hofmann and others, 2000). Benthic algae (collected solely at sites 2 and 4 ) had $\delta^{13} \mathrm{C}$ values that ranged from -12.8 to -16.3 permil, in general agreement with values for calcareous algae in this region (Craig, 1953) and in nearby Florida Bay (USA) (Walter and others, 2007). For comparison, bulk organic matter in Bahamas Bank sediments (which presumably represents some undefined mixture of all of these sources) ranges from approximately -10 permil to -14 permil (Scalan and Morgan, 1970; Rasmussen and others, 1990). 


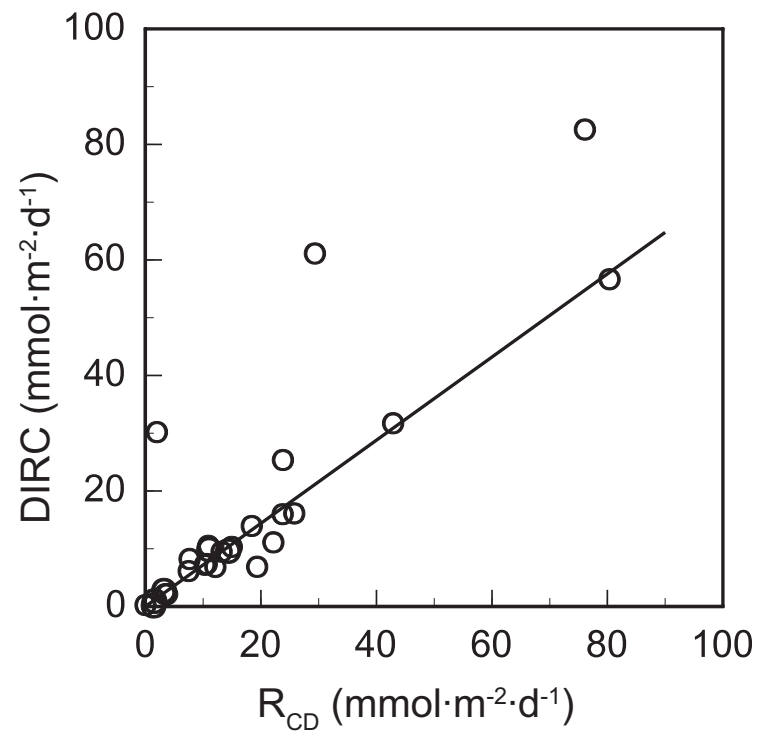

Fig. 8. The depth-integrated rate of sediment carbonate dissolution $\left(R_{\mathrm{CD}}\right)$ versus the depth-integrated rate of $\mathrm{Ca}^{2+}$ production (DIRC) for Bahamas Bank sediments (data from table 2 and Burdige and others, $2008)$. The solid best-fit line through the data is $D I R C=(0.72 \pm 0.02) \cdot R_{\mathrm{CD}}\left[\mathrm{n}=23 ; \mathrm{r}^{2}=0.95, \mathrm{p}<0.001\right]$. The three sites that fall significantly above this regression line were not included in the linear regression calculation, since these results have values of DIRC that are greater than $R_{\mathrm{CD}}$ (which is physically impossible). We believe that the small changes in $\left[\mathrm{Ca}^{2+}\right]$ observed in these sediments (relative to the observed changes for the other solutes) lead to large uncertainties in our model estimates of DIRC (see $\mathrm{Hu}, \mathrm{ms}, 2007$, for details).

When the seagrass isotope data in table 3 were pooled with results from our Lee Stocking Island sites ( $\mathrm{Hu}$ and Burdige, 2007) we observed that values of $\delta^{13} \mathrm{C}$ for Thalassia testudinum were negatively correlated with water depth $\left(\mathrm{r}^{2}=0.56, \mathrm{p}=0.005\right)$. In contrast, no similar relationship was observed at these same sites between bottom water DIC $\delta^{13} \mathrm{C}$ and water depth (Hu, ms, 2007). A more detailed discussion of these observations is presented elsewhere ( $\mathrm{Hu}$ and others, 2009), although here we have used this relationship to estimate the $\delta^{13} \mathrm{C}$ for Thalassia testudinum at sites where we did not make seagrass isotopic measurements.

Sediment carbonate had $\delta^{13} \mathrm{C}$ values that ranged from 3.9 to 4.7 permil (table 3 ), similar to other values reported in the literature for Bahamas Bank sediments (for example, Swart and others, 2009). At some sites $\delta^{13} \mathrm{C}$ values showed some down core variability (up to $\sim 1 \%$ ) but did not show any consistent trends with sediment depth (Hu, ms, 2007).

$\delta^{13} C$ of pore water DIC and calculation of $\delta^{13} C_{\text {added }}$. -Pore water DIC $\delta^{13} \mathrm{C}$ values were generally lower than bottom waters values (fig. 4), and at some sites they decreased with depth to a constant value below $\sim 10$ to $20 \mathrm{~cm}$. At other sites, $\delta^{13} \mathrm{C}$ first decreased and then increased with sediment depth, thus showing a mid-depth minimum, centered at $\sim 5 \mathrm{~cm}$. Both types of profiles are similar to those that we have observed previously in Lee Stocking Island sediments (Hu and Burdige, 2007).

The concentration and isotopic composition of DIC in the pore waters is altered by processes such as metabolic carbonate dissolution (eqs 1-3), which may also be coupled with reprecipitation reactions (Hu and Burdige, 2007). The net result of these processes is that total DIC concentrations increase with sediment depth (fig. 2), and the isotopic composition of the DIC being added to the pore waters by these processes 
TABLE 3

Isotopic data and results from mass balance calculations

\begin{tabular}{|c|c|c|c|c|c|c|c|}
\hline Site & $\delta^{13} C_{\text {added }}^{p w}(\% 0)^{\mathrm{a}}$ & $\mathrm{r}^{\mathrm{a}^{\mathrm{a}}}$ & $\mathrm{p}^{\mathrm{a}}$ & $\delta^{13} C_{\text {seagrass }}(\% 0)$ & $\delta^{13} C_{\text {carb }}(\%)$ & $\delta^{13} C_{\text {added }}^{\text {pred }}(\%)^{\mathrm{c}}$ & $D R I(\%){ }^{\mathrm{d}}$ \\
\hline 2 & $1.63 \pm 0.22$ & 0.90 & $<<0.01$ & $-6.32 \pm 0.12(\mathrm{~m})$ & $4.17 \pm 0.18$ & $-1.07 \pm 0.15$ & $2.70 \pm 0.11$ \\
\hline 3 & $-3.83 \pm 1.50$ & 0.23 & 0.02 & $-7.80 \pm 2.22(\mathrm{~m})$ & $4.18 \pm 0.04$ & $-1.81 \pm 1.13$ & $-2.02 \pm 1.11$ \\
\hline 4 & $0.61 \pm 1.64$ & 0.02 & 0.72 & $-8.92 \pm 0.19(\mathrm{~m})$ & $4.11 \pm 0.48$ & $-2.40 \pm 0.34$ & $3.01 \pm 0.26$ \\
\hline 5 & $-4.50 \pm 1.24$ & 0.69 & 0.01 & $-6.67 \pm 1.64(\mathrm{c})$ & $4.58 \pm 0.45$ & $-1.05 \pm 1.04$ & $-3.45 \pm 0.85$ \\
\hline 6 & $-0.18 \pm 1.05$ & 0.00 & 0.87 & $-7.94 \pm 1.95(\mathrm{c})$ & $4.48 \pm 0.58$ & $-1.73 \pm 1.27$ & $1.56 \pm 1.02$ \\
\hline 8 & $0.53 \pm 0.85$ & 0.07 & 0.56 & $-6.34 \pm 1.55(\mathrm{c})$ & $4.19 \pm 0.19$ & $-1.08 \pm 0.87$ & $1.61 \pm 0.78$ \\
\hline 9 & $1.34 \pm 2.60$ & 0.04 & 0.62 & $-6.45 \pm 1.58(\mathrm{c})$ & $4.68 \pm 0.24$ & $-0.89 \pm 0.91$ & $2.23 \pm 0.80$ \\
\hline 10 & $-5.41 \pm 1.66$ & 0.45 & 0.01 & $-6.73 \pm 1.65(c)$ & $4.34 \pm 0.02$ & $-1.19 \pm 0.83$ & $-4.21 \pm 0.82$ \\
\hline 11 & $1.43 \pm 0.28$ & 0.84 & $<0.01-$ & $7.11 \pm 0.12(\mathrm{~m})$ & $4.68 \pm 0.21$ & $-1.22 \pm 0.16$ & $2.65 \pm 0.12$ \\
\hline 12 & $3.93 \pm 1.98$ & 0.40 & 0.09 & $-5.63 \pm 0.09(\mathrm{~m})$ & $4.28 \pm 0.29$ & $-0.67 \pm 0.19$ & $4.60 \pm 0.15$ \\
\hline 13 & $1.10 \pm 0.27$ & 0.59 & $<0.01$ & $-4.86 \pm 0.52(\mathrm{~m})$ & $3.93 \pm 0.01$ & $-0.46 \pm 0.26$ & $1.56 \pm 0.26$ \\
\hline 14 & $-0.09 \pm 0.57$ & 0.00 & 0.88 & $-6.62 \pm 1.62(\mathrm{c})$ & $4.35 \pm 0.35$ & $-1.14 \pm 0.99$ & $1.05 \pm 0.83$ \\
\hline 15 & $1.63 \pm 0.31$ & 0.74 & $<0.01$ & $-5.63 \pm 1.38(\mathrm{c})$ & $4.40 \pm 0.06$ & $-0.62 \pm 0.72$ & $2.25 \pm 0.69$ \\
\hline 16 & $-1.07 \pm 1.62$ & 0.03 & 0.52 & $-6.67 \pm 1.64(\mathrm{c})$ & $3.89 \pm 0.09$ & $-1.39 \pm 0.86$ & $0.32 \pm 0.82$ \\
\hline 17 & $-0.30 \pm 27$ & 0.00 & 0.99 & $-7.72 \pm 1.89(\mathrm{c})$ & $4.71 \pm 0.19$ & $-1.51 \pm 1.04$ & $1.21 \pm 0.95$ \\
\hline 18 & $0.56 \pm 0.44$ & 0.13 & 0.23 & $-6.29 \pm 1.54(\mathrm{c})$ & $4.64 \pm 0.14$ & $-0.82 \pm 0.84$ & $1.39 \pm 0.77$ \\
\hline 20 & $-1.77 \pm 0.77$ & 0.64 & 0.10 & $-6.29 \pm 0.06(\mathrm{~m})$ & $4.49 \pm 0.15$ & $-0.90 \pm 0.10$ & $-0.87 \pm 0.08$ \\
\hline 24 & $-0.92 \pm 1.34$ & 0.07 & 0.52 & $-7.01 \pm 1.72(\mathrm{c})$ & $4.70 \pm 0.35$ & $-1.15 \pm 1.03$ & $0.23 \pm 0.88$ \\
\hline 25 & $-2.54 \pm 0.57$ & 0.77 & $<0.01$ & $-8.49 \pm 1.39(\mathrm{~m})$ & $4.57 \pm 0.33$ & $-1.96 \pm 0.86$ & $-0.58 \pm 0.71$ \\
\hline
\end{tabular}

${ }^{\text {a }} \delta^{13} C_{\text {added }}^{p w}$ is the best-fit slope of a plot of $\left(\delta^{13} C_{\text {DIC }}\right) \cdot$ [DIC] versus [DIC] for each station. See sub-subsection $\delta^{13} C$ of pore water DIC and calculation of $\delta^{13} C_{\text {added }}-$ under subsection $\delta^{13} C$ Results of RESULTS for details. $r^{2}$ is the correlation coefficient of the regression, and $\mathrm{p}$ is the power of the linear regression.

b $(m)$ indicates values that were measured, whereas (c) indicates values that were calculated using a linear relationship between water depth and $\delta^{13} C_{\text {seagrass }}$ we have observed on the Bahamas Bank. See sub-subsection $\delta^{13} C$ of the sediment organic matter sources and carbonate sediments. - under subsection $\delta^{13} C$ Results of RESULTS and $\mathrm{Hu}$ (ms, 2007) for details.

${ }^{\mathrm{c}} \delta^{13} C_{\text {added }}^{\text {pred }}$ was calculated as discussed in subsection titled Stable carbon isotopic evidence for carbonate dissolution/reprecipitation of DISCUSSION.

${ }^{\mathrm{d}}$ As discussed in section titled Stable carbon isotopic evidence for carbonate dissolution/reprecipitation of Discussion, $D R I=\delta^{13} C_{\text {added }}^{p w}-\delta^{13} C_{\text {added }}^{\text {pred }}$.

$\left(\delta^{13} \mathrm{C}_{\text {added }}\right)$ can be determined in two ways. The first involves plotting $\left(\delta^{13} \mathrm{C}_{\text {DIC }}\right) \cdot[\mathrm{DIC}]$ versus [DIC] for a particular site, since the slope of the best-fit line from such a plot of data is equal to $\delta{ }^{13} \mathrm{C}_{\text {added }}$ (Sayles and Curry, 1988; Hu and Burdige, 2007). The results of these linear regressions are shown in table 3 (values referred to here as $\delta^{13} C_{a d d e d}^{p w}$ ), and three examples of such regressions at sites with varying seagrass densities are shown in figure 9 .

A second approach to calculate $\delta^{13} C_{a d d e d}^{p w}$ involves plotting $\delta^{13} \mathrm{C}_{\mathrm{DIC}}$ against $1 /$ [DIC], since here the y-intercept of the best-fit line through these data can be shown to equal $\delta^{13} C_{\text {added }}$ (for details, see Zeebe and Wolf-Gladrow, 2001). Values of $\delta^{13} C_{a d d e d}^{p w}$ obtained using these two procedures were not significantly different from each other (paired t-test, $p>0.05$ ), and the RMS error between these two sets of $\delta^{13} C_{\text {added }}^{p w}$ values was $\sim 0.14$ permil, less than the analytical uncertainty of the measurements of the $\delta^{13} \mathrm{C}$ of pore water DIC (Sample Collection and Analytical Methods section). For consistency with our previous work ( $\mathrm{Hu}$ and Burdige, 2007), in the discussion here we will use values of $\delta^{13} C_{\text {added }}^{p w}$ based on the first type of regression.

Among the 20 sites with available pore water DIC $\delta^{13} \mathrm{C}$ data, linear regressions for eight sites yielded statistically significant values $(\mathrm{p}<0.05)$, with two additional sites having $\mathrm{p}$ values between 0.05 and 0.10 . The $\delta^{13} C_{\text {added }}^{p w}$ values for these regressions ranged from $-5.4 \pm 1.7$ permil (site 10) to $+3.9 \pm 2.0$ permil (site 12). For the remaining regressions with higher $\mathrm{p}$ values, $\delta^{13} C_{a d d e d}^{p w}$ values were often times essentially indistinguishable from 0 permil (table 3 ). 

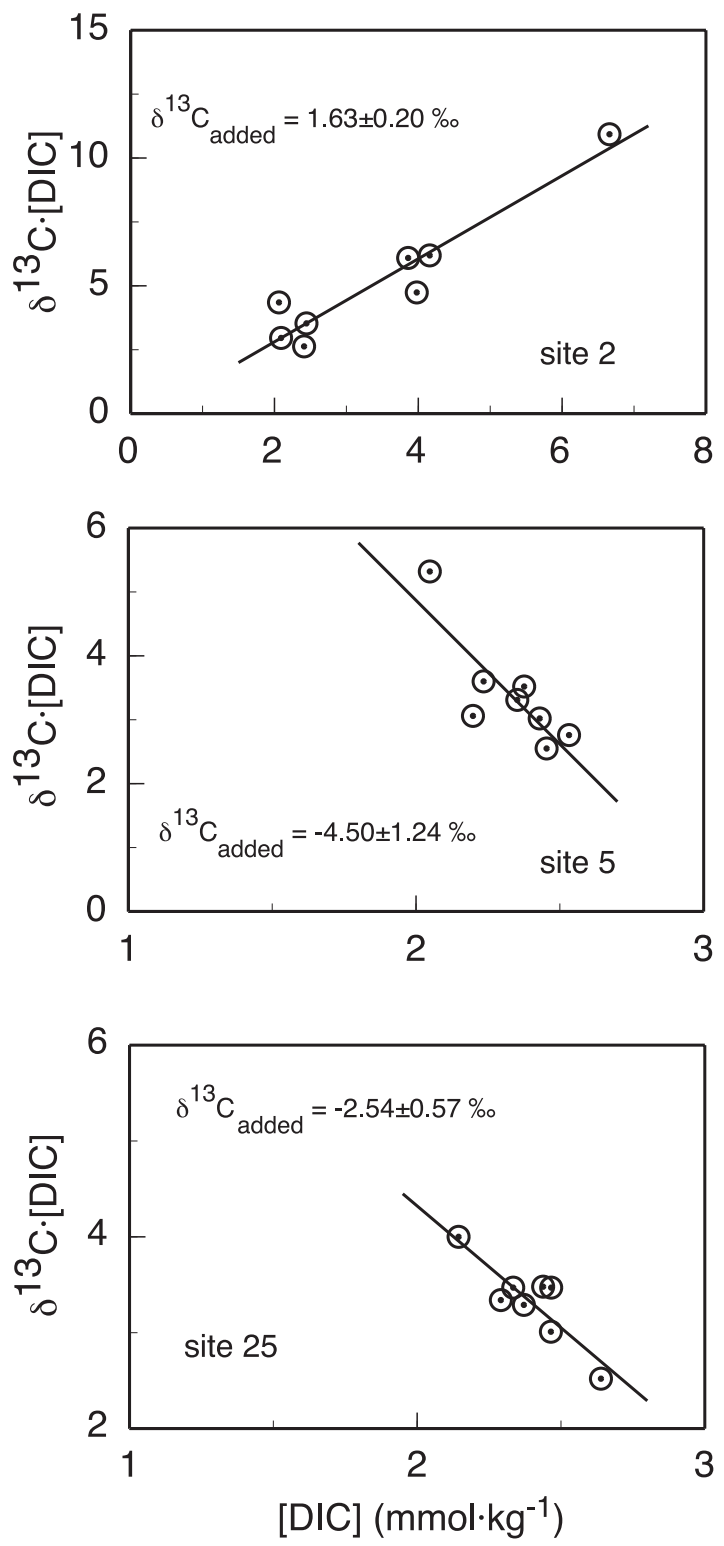

Fig. 9. Plots of $\delta^{13} \mathrm{C} \cdot[\mathrm{DIC}]$ versus [DIC] for selected sites on the Bahamas Bank. Note the different axes on each figure, and that $\delta^{13} \mathrm{C} \cdot[\mathrm{DIC}]$ is the product of the $\delta^{13} \mathrm{C}$ of the pore water DIC and the pore water DIC concentration. The slope of the best-fit line through each data set is the $\delta^{13} \mathrm{C}$ of the DIC being added to the pore waters at the site $\left(\delta^{13} C_{\text {added }}^{p w}\right.$; see table 3$)$.

\section{DISCUSSION}

\section{General Observations}

Metabolic carbonate dissolution.-The trends in the pore water data presented here-increases of carbonate dissolution end-products $\left(\mathrm{A}_{\mathrm{T}}, \mathrm{DIC}\right.$, and $\left.\mathrm{Ca}^{2+}\right)$ with depth, coupled with decreases in $\mathrm{O}_{2}$ concentration, $\mathrm{pH}$, and carbonate mineral saturation states-provide evidence for the occurrence of metabolic carbonate dissolu- 
tion (that is, eqns. 1-3) in these Bahamas Bank sediments. Consistent with the stoichiometry of this process, a plot of pore water $\Delta \mathrm{A}_{\mathrm{T}}$ versus $\Delta \mathrm{DIC}$ for these sediments was linear with a slope of $\sim 1$ (fig. $5 \mathrm{~A}$ ). A similar linear covariance of $\mathrm{A}_{\mathrm{T}}$ and DIC will also be seen if net sulfate reduction occurs in the absence of carbonate dissolution. However, the lack of pore water sulfate depletion and sulfide accumulation in these sediments (fig. 3) suggests that sulfate reduction, if it occurred, was tightly coupled with sulfide re-oxidation. Furthermore, the overall effect of this tightly coupled sulfur redox cycling in terms of metabolic carbonate dissolution is equivalent to aerobic respiration (Hu and Burdige, 2007; Burdige and others, 2008). Increases in pore water $\mathrm{Ca}^{2+}$ with sediment depth also track increases in pore water $\mathrm{A}_{\mathrm{T}}$ and DIC, and further argue for the occurrence of metabolic carbonate dissolution, rather than sulfate reduction, in causing the build-up of these pore water solutes.

In figure 5A there was also a negative $y$-intercept (or positive $\mathrm{x}$-intercept) in the plot of $\Delta \mathrm{A}_{\mathrm{T}}$ versus $\Delta \mathrm{DIC}$. Since the bottom waters at these sites were supersaturated with respect to all carbonate mineral phases (see fig. 3), the value of this $\mathrm{x}$-intercept $\left(107 \pm 3 \mu \mathrm{mol} \cdot \mathrm{kg}^{-1}\right.$ ) can approximately be thought of as the amount of DIC (or aqueous $\mathrm{CO}_{2}$ ) initially added to the pore waters that titrates the available dissolved carbonate ion, and therefore lowers the saturation state of the pore waters. Once the pore waters become sufficiently undersaturated with respect to the most soluble carbonate phase in the sediments dissolution occurs, the alkalinity and DIC increase in roughly a 1:1 fashion (Moulin and others, 1985; Burdige and Zimmerman, 2002), and $\left[\mathrm{CO}^{2-}\right]$ remains roughly constant with depth.

To further examine this possibility, we first estimated an average bottom water $\left[\mathrm{CO}_{3}^{2-}\right]$ concentration $\left(185 \mu \mathrm{mol} \cdot \mathrm{kg}^{-1}\right)$ at the sites we studied, assuming an average bottom water DIC concentration of $2.07 \mathrm{mmol} \cdot \mathrm{kg}^{-1}$ and $\mathrm{pH}$ of 8.04 (see the Sample Collection and Analytical Methods section for details). If we next add $107 \mu \mathrm{mol} \cdot \mathrm{kg}^{-1}$ of DIC to this water (with no addition of alkalinity), the resulting value of $\left[\mathrm{CO}_{3}^{2-}\right]$ decreases to $120 \mu \mathrm{mol} \cdot \mathrm{kg}^{-1}$, a value that is consistent with the asymptotic pore water $\left[\mathrm{CO}_{3}^{2-}\right]$ calculated for the sediments of our study $\left(80-140 \mu \mathrm{mol} \cdot \mathrm{kg}^{-1} ; \mathrm{Hu}, \mathrm{ms}, 2007\right)$.

Sediment-seagrass interactions and sediment carbonate dissolution.-Sediment incubation studies show that $\mathrm{O}_{2}$ input strongly controls the rate of carbonate dissolution in Bahamas Bank sediments, since carbonate dissolution rates are fast compared to sediment $\mathrm{O}_{2}$ consumption ( $\mathrm{Hu}$ and Burdige, 2008). As a result, the carbonate dissolution rates we observe are strongly correlated with seagrass density (that is, LAI; see fig. 7), since seagrass $\mathrm{O}_{2}$ pumping represents a major source of oxygen to these sediments (Burdige and others, 2008).

In Lee Stocking Island sediments we also saw a positive relationship between pore water concentrations of carbonate dissolution end-products such as alkalinity and DIC and LAI (Burdige and others, 2008). When similar plots are made using the results of this study (fig. 10A) we see that many of the sites follow a similar trend of increasing $\triangle \mathrm{DIC}$ with increasing $L A I$. However we also see that there are a group of sites (sites 3,4 , $12,17,20,24$ and 25) for which $\Delta$ DIC values are quite low (less than $\sim 1 \mathrm{mmol} \cdot \mathrm{kg}^{-1}$ ) for $L A I$ values that range from a relatively low value of $\sim 0.5$ to a high value of almost 4 . Despite this trend in $\triangle \mathrm{DIC}$ vs. $L A I$ the model-derived rates of carbonate dissolution in these low $\triangle$ DIC sediments are not anomalously low (fig. 7, table 2). Interestingly, all but one of these sites (site 12) are found near the northern or western edge of the Great Bahamas Bank in close proximity to the deeper water of the Straits of Florida or Northeast Providence Channel (see fig. 1).

In examining these trends, we note that advective pore water exchange, which contributes to the oxygen input that drives carbonate dissolution in Bahamas Bank sediments, also plays a role in the efficient removal of carbon oxidation and carbonate dissolution end products such as DIC and $\mathrm{A}_{\mathrm{T}}$ (Burdige and others, 2008). Furthermore 


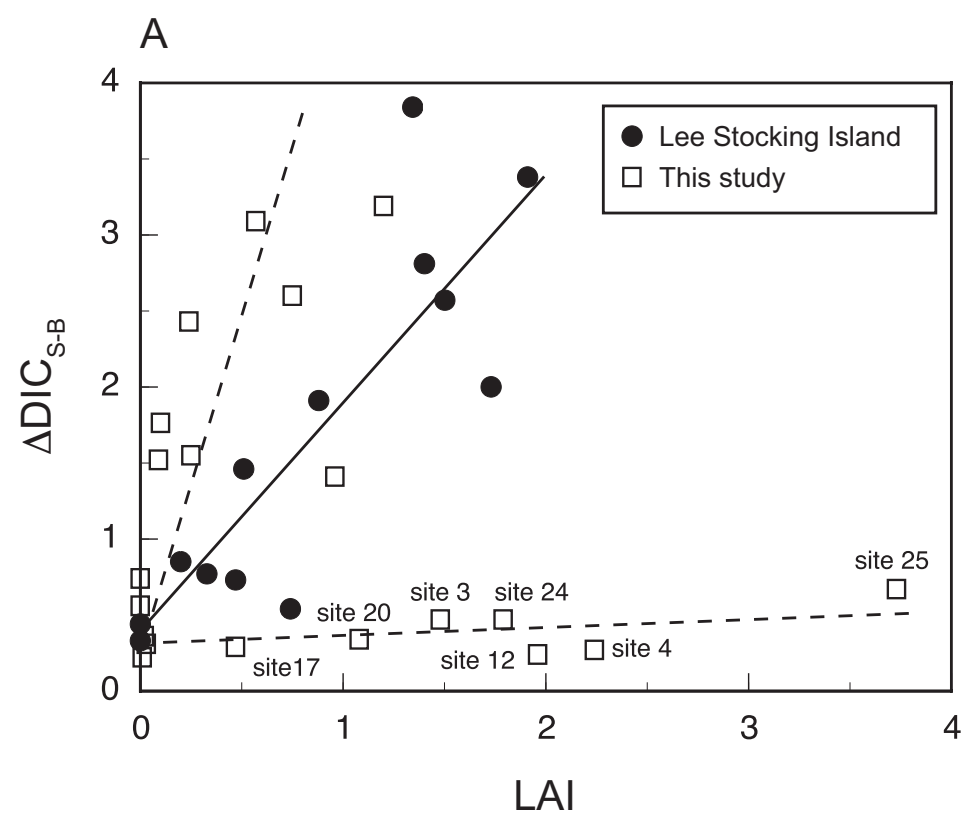

B

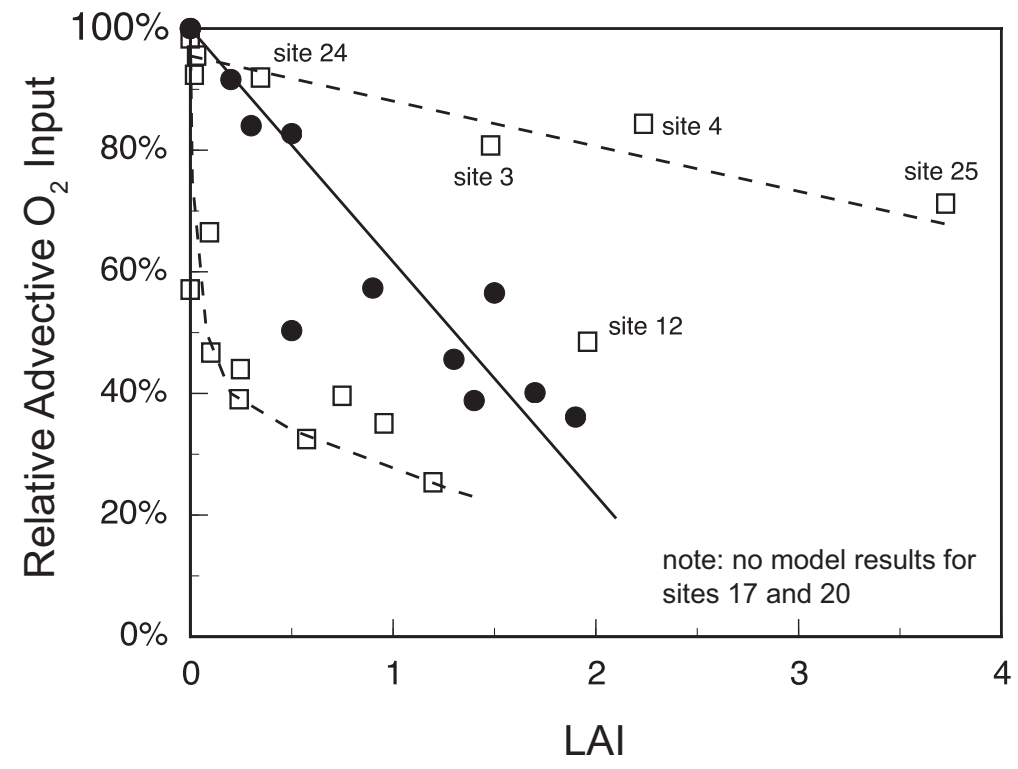

Fig. 10. (A) A plot of $\triangle \mathrm{DIC}_{\mathrm{S}-\mathrm{B}}$ vs. $L A I$ (leaf area index) for sediments on the Bahamas Bank (Lee Stocking Island data from Burdige and others, 2008). $\Delta \mathrm{DIC}_{\mathrm{S}-\mathrm{B}}$ is defined here as the difference between the average pore water concentration between 10 and $20 \mathrm{~cm}$ and the bottom water concentration. Note that the results from this study appear to show two distinct trends; one in which $\triangle \mathrm{DIC}_{\mathrm{S}-\mathrm{B}}$ increases with $L A I$ (similar to that seen here for the Lee Stocking Island sites), and one in which $\triangle \mathrm{DIC}_{\mathrm{S}-\mathrm{B}}$ values are relatively low and show very small changes with increasing $L A I$. (B) Relative advective $\mathrm{O}_{2}$ input (advective sediment $\mathrm{O}_{2}$ input as a \% of TSOI [total sediment oxygen uptake]) versus $L A I$ for the sediments on the Bahamas Bank. The calculation of relative $\mathrm{O}_{2}$ input is done with results from our pore water ADR model (Pore Water Modeling section) and is described in detail in Burdige and others (2008). Note that as in panel A, results from this study show two distinct trends, and that the sediments for which relative advective $\mathrm{O}_{2}$ input remain high with increasing in $L A I$, also show low values of $\triangle \mathrm{DIC}_{\mathrm{S}-\mathrm{B}}$. 
in this work we suggested that advective pore water exchange leads to the apparent preferential transport of these solutes out of these sediments relative to the advective input of oxygen, because the $\mathrm{O}_{2}$ concentration difference between bottom waters and pore waters is roughly an order-of-magnitude smaller than similar differences for DIC and $\mathrm{A}_{\mathrm{T}}$. However, in the low $\triangle \mathrm{DIC}$ sediments of this study we see that this effect appears to be amplified relative to that observed at other of our sites, since modelderived advective $\mathrm{O}_{2}$ input is of greater percentage of total sediment $\mathrm{O}_{2}$ input in these low $\triangle$ DIC sediments than it is at either of the other sites we studied here or the Lee Stocking Island sites (fig. 10B).

The reasons for this are not well understood at the present time, and a more detailed discussion of these observations is beyond the scope of this work. However we do feel that this observation is related in some fashion to how bottom water flow and the seagrass canopy interact with each other and lead to this advective exchange, as discussed, for example, by Koch and Gust (1999). Sites around Lee Stocking Island are dominated by diurnal tides (Burdige and others, 2008), and strong uni-directional flow occurs over each half of the tidal cycle. In contrast, many of the sites in this present study are farther away from land and short-term, oscillatory, wave-dominated motion is likely more important than tidal motion in generating the pressure gradients that drive advective pore water exchange. Bottom water pressure gradients at these sites may also be caused by the formation of Langmuir cells and their associated short-term oscillatory bottom water motion (Dierssen and others, 2009a, 2009b). Thus while seagrass density appears to be a reasonable "master variable" to parameterize rates of carbonate dissolution in Bahamas Bank sediments (fig. 7), our results also demonstrate that sediment $\mathrm{O}_{2}$ input (which ultimately drives carbonate dissolution) is controlled by more than simply seagrass oxygen pumping.

Preferential dissolution of HMC.-Thermodynamic considerations and model calculations (Walter and Morse, 1984; Morse and others, 2006) as well as past field studies all provide evidence for the preferential dissolution of $\mathrm{HMC}$, versus aragonite, in Bahamas Bank sediments (Morse and others, 1985; Walter and Burton, 1990; Burdige and Zimmerman, 2002).

Other results similarly provide evidence for a magnesian calcite phase such as HMC undergoing preferential dissolution in the sediments of this study. Pore water property-property plots such as $\Delta\left[\mathrm{Ca}^{2+}\right]$ versus $\Delta \mathrm{DIC}$ (fig. $5 \mathrm{~B}$ ) can, in principle, be used to examine reaction stoichiometry if the relevant transport properties (for example, diffusion, bioirrigation) are properly incorporated into the calculation (Berner, 1977; Hammond and others, 1999; Burdige, 2006). However, the ability to carry out this calculation in high permeability sediments, where physical advection dominates mass transport near the sediment-water interface, has not been examined in the same detail as it has been in more muddy sediments, where diffusion and/or bioirrigation dominate pore water transport. Thus it is not clear how the slope of the best-fit line in figure $5 \mathrm{~B}$ can be used to estimate the composition of the carbonate phase undergoing dissolution.

Alternately, we can address this problem by examining the slope of the best-fit line from the plot of DIRC versus $R_{\mathrm{CD}}$ in figure 8 . Since transport processes such as advective pore water exchange are explicitly incorporated into these rate estimates (see the Pore Water Modeling section for details), this approach is more robust than that discussed above. Taken at face value, the slope of the best-fit line in figure $8(0.73 \pm$ 0.02 ) predicts that $\mathrm{HMC}$ with $\sim 27$ mole percent $\mathrm{Mg}$ is undergoing dissolution in these sediments.

In contrast, our XRD results showed that the Mg content of the HMC in Bahamas Bank sediments we studied was $\sim 12$ to 13 mole percent, similar to that observed in studies of other Bahamas Bank sediments (Berner, 1966; Morse and others, 1985; Hu 
and Burdige, 2007). Furthermore, the Mg content of HMC in shallow water carbonate sediments averages, in general, $\sim 13$ to 14 mole percent, with a typical range of $\sim 10$ to 18 mole percent (Milliman, 1974; Morse and Mackenzie, 1990). As we have discussed previously ( $\mathrm{Hu}$ and Burdige, 2008) we believe that the explanation of these seemingly contradictory results is that the sediment carbonate dissolution we are observing is incongruent dissolution, in which HMC dissolution is accompanied by the reprecipitation of a secondary carbonate phase with a lower $\mathrm{Mg}$ content. This coupled dissolution/reprecipitation process can then sustain a disproportional increase in $\left[\mathrm{Ca}^{2+}\right]$ relative to the Ca content of the sediment HMC undergoing dissolution, and lead to the apparent observation of a more $\mathrm{Mg}$-rich carbonate phase undergoing dissolution.

\section{Pore Water Evidence for Coupled Dissolution/Reprecipitation}

As noted in the INTRODUCTION, several studies have presented geochemical evidence for coupled carbonate dissolution and reprecipitation during postdepositional diagenesis (Rude and Aller, 1991; Patterson and Walter, 1994; Walter and others, 2007; Hu and Burdige, 2008), and processes such as micritization and/or the formation of carbonate cements also appear to involve dissolution and reprecipitation (see discussions in Reid and Macintyre, 2000; Morse, 2003).

Dissolution/reprecipitation during the early diagenesis of carbonate minerals may occur because of differences in the solubility of carbonate phases such as calcite, aragonite or HMC; pore waters which are undersaturated with respect to one or more metastable phases may still be supersaturated with respect to another of these phases. Thus in these sediments there may be net dissolution of a more soluble carbonate phase that represents the balance between gross dissolution of this phase and reprecipitation of a more stable phase (for example, Hu and Burdige, 2008).

While the secondary phase that forms may indeed be a different carbonate mineral (for example, Rude and Aller, 1991), the thermodynamic driving force for dissolution/reprecipitation may alternatively be described as "Ostwald ripening." In this process smaller crystals dissolve and reprecipitate as larger crystals, thereby reducing the surface free energy of the small particles (Morse and Casey, 1988). This process also occurs with little or no change in mineralogy, and here, for example, the HMC that reprecipitates may have a very similar (although perhaps slightly lower) $\mathrm{Mg}$ content relative to the original starting material (Hover and others, 2001).

Stable isotope results in both Lee Stocking Island sediments ( $\mathrm{Hu}$ and Burdige, 2007) and South Florida carbonate platform sediments (Walter and others, 2007) provided evidence for the occurrence of such processes, as do recent sediment incubation studies with Bahamas Bank sediments from around Lee Stocking Island and sites 3 and 13 of this study (Hu and Burdige, 2008). In these studies we were able to apply a simple closed system dissolution/reprecipitation model to our results to show that if the dissolving carbonate phase was 12 mole percent $\mathrm{Mg} \mathrm{HMC}$, then the secondary phase that formed was also $\mathrm{HMC}$ with $\sim 8$ mole percent $\mathrm{Mg}$. This latter observation agrees with previous studies (Morse and Mucci, 1984) in which HMC overgrowths with $\sim 8$ mole percent $\mathrm{Mg}$ formed on the surface of Iceland spar (crystallized calcite mineral) buried in Bahamian sediments for 3 to 9 months (also see similar results in Berner, 1975; Mucci, 1986; Mucci, 1987; Tribble and Mackenzie, 1998). Thermodynamic calculations (Morse and others, 2006) also suggest that the equilibrium HMC which should form abiotically in seawater has $\sim 8$ mole percent $\mathrm{Mg}$. Finally, Hover and others (2001) showed that the Mg-content of HMC in altered foraminifera tests from Florida Bay and Bahamas Bank sediments was only $\sim 1$ to 3 mole percent lower than that in living specimens (which had a starting composition of 13-14 mole $\% \mathrm{Mg}$ ). 
To further examine dissolution/reprecipitation with our pore water results we use the following two equations,

$$
\begin{gathered}
\mathrm{Ca}_{a} \mathrm{Mg}_{(1-a)} \mathrm{CO}_{3}+\mathrm{CO}_{2}+\mathrm{H}_{2} \mathrm{O} \stackrel{R_{C D}+J_{r p}}{\longrightarrow} a \mathrm{Ca}^{2+}+(1-a) \mathrm{Mg}^{2+}+2 \mathrm{HCO}_{3}^{-} \\
b \mathrm{Ca}^{2+}+(1-b) \mathrm{Mg}^{2+}+2 \mathrm{HCO}_{3}^{-} \stackrel{J_{\phi p}}{\rightarrow} \mathrm{Ca}_{b} \mathrm{Mg}_{(1-b)} \mathrm{CO}_{3}+\mathrm{H}_{2} \mathrm{O}+\mathrm{CO}_{2}
\end{gathered}
$$

where $a$ is the calcium content of the original carbonate undergoing dissolution, $b$ is that of the reprecipitated carbonate, and $R_{\mathrm{CD}}$ and $J_{\mathrm{rp}}$ are the depth-integrated rates of net carbonate dissolution and reprecipitation, respectively. Given these equations, the depth-integrated rate of net $\mathrm{Ca}^{2+}$ production $(D I R C)$ can be written as,

$$
D I R C=a \times\left(R_{C D}+J_{r p}\right)-b \times J_{r p}
$$

Since the results in figure 8 indicate that DIRC is roughly a constant fraction of $R_{\mathrm{CD}}$ (that is, DIRC $=\gamma \cdot R_{\mathrm{CD}}$, where $\gamma=0.73 \pm 0.02$ ), eq (6) can be re-written as,

$$
\frac{J_{r p}}{R_{C D}}=\frac{\gamma-a}{a-b}=R_{r x}
$$

where $R_{\mathrm{rx}}$ is defined as the reprecipitation ratio (Hu and Burdige, 2007, 2008).

In using equation (7) to estimate $R_{\mathrm{rx}}$ we assume that 12 mole percent Mg HMC undergoes gross dissolution (that is, $a=0.88$; see XRD results in the Study Sites section), and based on the discussion above we consider two possibilities for the composition of the carbonate phase that is reprecipitated- $\mathrm{Ca}_{0.92} \mathrm{Mg}_{0.08} \mathrm{CO}_{3}$ ( $b=$ $0.92)$ and $\mathrm{CaCO}_{3}(b=1)$. The latter is a carbonate phase with no $\mathrm{Mg}$, that is, aragonite or calcite, while the former phase is 8 mole percent $\mathrm{Mg} \mathrm{HMC}$.

These values of $a, b$, and $\gamma$ predict values of $R_{\mathrm{rx}}$ that range from 1.3 to 3.8. These calculations are, however, somewhat sensitive to the assumed composition of the carbonate phase undergoing dissolution. For example, if this phase is 15 mole percent Mg HMC (for example Bischoff and others, 1993), then values of $R_{\mathrm{rx}}$ decrease to 0.8 to 1.7. These uncertainties notwithstanding, the range of $R_{\mathrm{rx}}$ values estimated here are consistent with values reported in the literature (see table 4), despite the distinctively different approaches used in all of these studies. This agreement therefore suggests that not only is carbonate reprecipitation a common feature of the early diagenesis of shallow water carbonate sediments, but also that the rate of reprecipitation is nearly a constant fraction of the rate of net, and gross, dissolution. ${ }^{1}$

\section{Stable Carbon Isotope Evidence for Carbonate Dissolution/Reprecipitation}

If carbonate dissolution and organic carbon oxidation are the sole processes that contribute DIC to the pore waters, then the following mass balance equation can be written (Hu and Burdige, 2007),

$$
\delta^{13} C_{\text {added }}=f_{O M} \times \delta^{13} C_{O M}+f_{C} \times \delta^{13} C_{C}
$$

$$
\begin{aligned}
& { }^{1} \text { If } \frac{J_{r p}}{R_{C D}}=R_{r x} \text { and } J_{r p}+R_{C D}=R_{G D} \text { where } R_{G D} \text { is the depth-integrated rate of gross carbonate dissolution, } \\
& \text { then } \frac{J_{r p}}{R_{G D}}=\frac{1+R_{r x}}{R_{r x}} \text {. }
\end{aligned}
$$


TABLE 4

Reprecipitation ratio $\left(R_{r x}\right)$ in shallow water carbonate sediments

\begin{tabular}{lcl}
\hline Location & $R_{r x}\left(\right.$ or $\left.J_{\mathrm{rp}} / R_{\mathrm{CD}}\right)$ & \multicolumn{1}{c}{ Method of analysis } \\
\hline \hline Lee Stocking Island (Hu and Burdige, 2007) & $3.3-3.8$ & $\begin{array}{l}\text { Closed system carbon isotope model applied to } \\
\text { pore water profiles }\end{array}$ \\
$\begin{array}{l}\text { Bahamas Bank (Hu and Burdige, 2008) } \\
\text { Closed system carbon isotope model applied to } \\
\text { sediment incubation data }\end{array}$ \\
$\begin{array}{l}\text { Bahamas Bank (this work) } \\
\text { Inverse pore water ADR model and Ca mass } \\
\text { balance }\end{array}$ \\
$\begin{array}{l}\text { Florida Bay mudbank/Bahamas Bank (Walter } \\
\text { and others, 1993) }\end{array}$ & $1.1-2.1-3.8$ & $\begin{array}{l}\text { Closed-system incubations and a calcium isotope } \\
\text { model } \\
\text { Florida Bay mudbank (Rude and Aller, 1990) }\end{array}$ \\
$\begin{array}{l}\text { Florida Bay mudbank/ Atlantic reef tract bank } \\
\text { (Walter and others, 2007) }\end{array}$ & $2.8-3.3$ & $\begin{array}{l}\text { Total carbon and carbon isotope mass balance } \\
\text { calculations }\end{array}$ \\
\hline
\end{tabular}

where the subscript "C" indicates sediment carbonate, subscript "OM" indicates sediment organic matter, and $f_{O M}=f_{C}=0.5$ based on the stoichiometry of metabolic carbonate dissolution (that is, eqn. 3). Using the measured values of $\delta^{13} \mathrm{C}_{\mathrm{C}}$ in table 3 , and assumed values of $\delta^{13} \mathrm{C}_{\mathrm{OM}}$ (see below), we can then estimate the value of $\delta^{13} \mathrm{C}_{\text {added }}$ using equation (8). These values are also shown in table 3 , listed here as $\delta^{13} C_{\text {added }}^{\text {pred }}$.

In seagrass sediments in oligotrophic tropical environments, seagrass detritus is often the dominant carbon source for microbial respiration since other types of carbon sources (for example, algal detritus) are less prevalent (Boschker and others, 2000; Holmer and others, 2001; Jones and others, 2003; Bouillon and Boschker, 2006). Therefore at sites where $L A I$ is greater than 0 , we have used the measured or estimated values of $\delta^{13} \mathrm{C}_{\text {seagrass }}$ for $\delta^{13} \mathrm{C}_{\mathrm{OM}}$ in the calculation of $\delta^{13} C_{\text {added }}^{\text {pred }}$. In calculations at the two sites where $L A I=0$ (sites 6 and -9 ), we have also assumed that the value of $\delta^{13} \mathrm{C}_{\mathrm{OM}}$ for sediments is that of seagrasses growing at the same water depth as these sites. This value likely represents an upper limit for the isotopic composition of sediment organic matter at these sites, since if the organic matter undergoing remineralization in these sediments was a mixture of seagrass, benthic algal, and phytoplankton detritus, its $\delta^{13} \mathrm{C}$ would be lighter (more negative) than that of seagrass alone (see the $\delta^{13} C$ of pore water DIC and calculation of $\delta^{13} C_{\text {added }}$ section, discussions below, and discussions in $\mathrm{Hu}$ and Burdige, 2007).

If we now compare values of $\delta^{13} C_{\text {added }}^{\text {pred }}$ with values of $\delta^{13} C_{\text {added }}^{p w}$ we see that the sediments of this study can be roughly divided into 3 groups:

1. $\delta^{13} C_{\text {added }}^{p w}>\delta^{13} C_{\text {added }}^{\text {pred }}$-sites $2,4,6,8,9,11,12,13,14,15$, and 18;

2. $\delta^{13} C_{\text {added }}^{\text {pwwe }} \approx \delta^{13} C_{\text {added }}^{\text {pred }}$-sites $16,17,24$, and 25 ;

3. $\delta^{13} C_{\text {added }}^{p w}<\delta^{13} C_{\text {added }}^{p \text { pred }}$-sites $3,5,10$, and 20;

We next define $\delta^{13} C_{\text {added }}^{p w}-\delta^{13} C_{\text {added }}^{\text {pred }}$ as $D R I$, which we can use here as an isotopic indicator for dissolution/reprecipitation in these sediments. Based on this definition of $D R I$, the group 1 sediments have positive $D R I$ values, the group 3 sediments have negative $D R I$ values and the group 2 sediments have $D R I$ values $\sim 0$. At all of these sites, $D R I$ showed a weak, but significant, inverse correlation with sediment grain size (fig. $11 \mathrm{~A}$ ). In contrast, $D R I$ showed no significant correlation with either $L A I$ (fig. 11B) or $R_{\mathrm{CD}}$ (not shown here).

Focusing first on the group 1 sediments we note that positive values of $D R I$ imply that the DIC being added to the pore waters is heavier than that predicted as described 

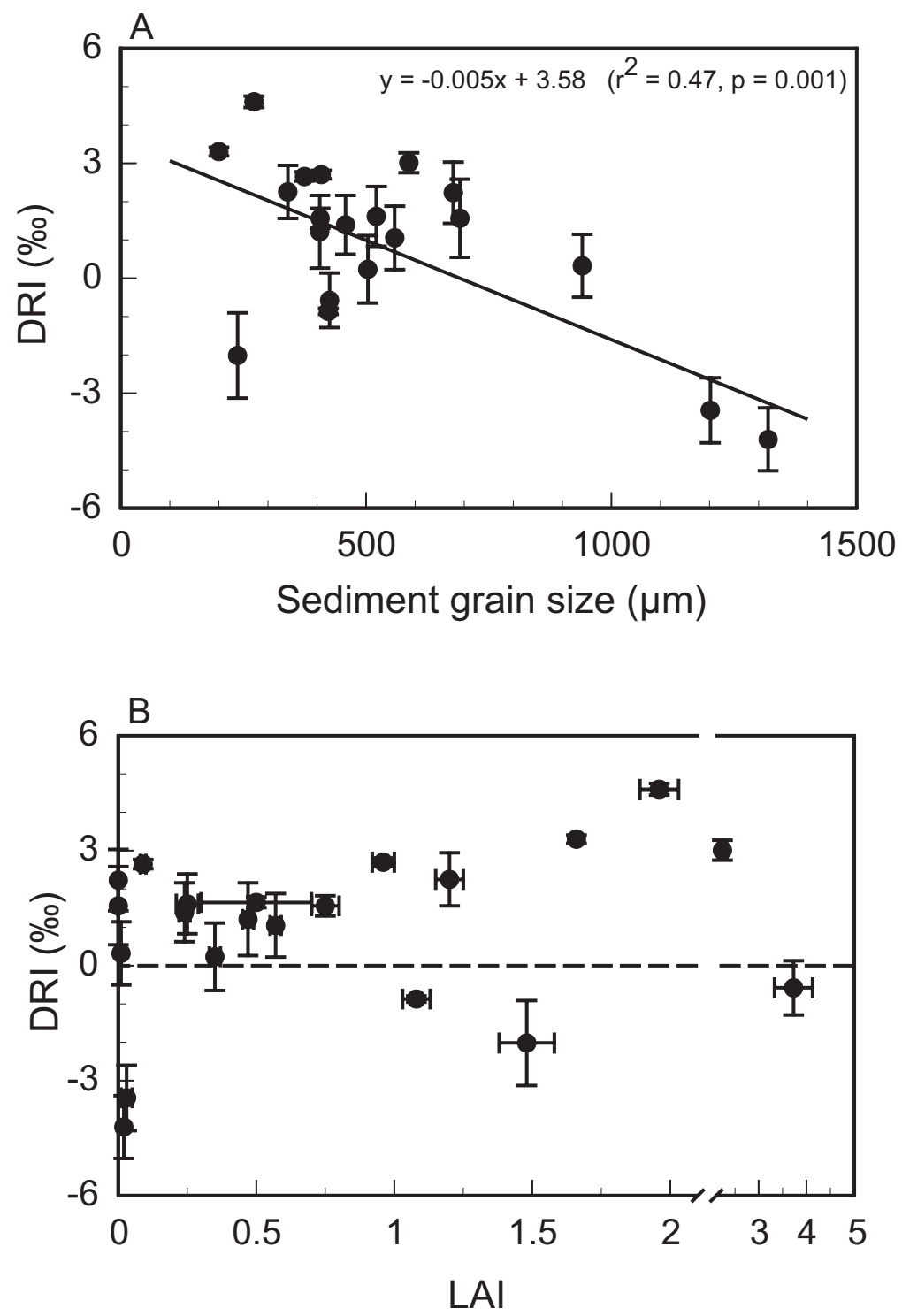

Fig. 11. (A) DRI (defined in Stable carbon isotope evidence for carbonate dissolution/reprecipitation section) versus mean sediment grain size for sediments on the Bahamas Bank (data from tables 1 and 3 and Hu and Burdige, 2007). (B) DRI versus $L A I$ for these same sites. As discussed in the text, these data showed no significant correlation $\left(\mathrm{r}^{2}=0.01, \mathrm{p}=0.68\right)$. A similar lack of correlation was seen between $D R I$ and $R_{\mathrm{CD}}$ (results not shown here).

above. Based on the definition of $\delta^{13} \mathrm{C}_{\text {added }}$ in equation 8 , this would seem to imply that an organic carbon source that is isotopically heavier than seagrass is undergoing remineralization. However, all plausible alternate organic matter sources to these sediments (that is, benthic algae or phytoplankton) have $\delta^{13} \mathrm{C}$ values that are lighter (more negative) than seagrasses (see the $\delta^{13} C$ of pore water DIC and calculation of $\delta^{13} C_{\text {added }}$ section). Based on these observations, and additional arguments presented elsewhere ( $\mathrm{Hu}$ and Burdige, 2007), we have therefore taken these observations as 
further independent evidence (in addition to pore water evidence discussed in the previous section) for the occurrence of coupled carbonate dissolution/reprecipitation in these sediments, with seagrass organic matter dominating sediment organic matter remineralization. This process enriches the pore water DIC pool with ${ }^{13} \mathrm{C}$, and leads to "apparent" heavy values of $\delta^{13} C_{\text {added }}^{p w}$, as a result of heavy sediment carbonate carbon $\left(\delta^{13} \mathrm{C} \approx 4-5 \% o\right)$ passing through the DIC pool during dissolution followed by reprecipitation (also see $\mathrm{Hu}$ and Burdige, 2008, for further details).

An alternate explanation for the observation of positive $D R I$ values is that the specific carbonate phase undergoing dissolution is isotopically heavier than that of the bulk sediments. However, we believe that this is unlikely since HMC, the phase that appears to undergo preferential dissolution in these sediments, is generally isotopically lighter than aragonite, which typically has a $\delta^{13} \mathrm{C}$ value $>+4$ permil (for example, Swart and others, 2009). This isotopic composition for aragonite is consistent with the bulk sediment $\delta^{13} \mathrm{C}$ values observed in the sediments of this study (table 3 ), which is itself not surprising since aragonite represents 80 to 90 percent of the total material in these sediments.

The two sites (sites 6 and 9) at which seagrasses are absent (that is, $L A I=0$ ) are classified here as group 1 sediments, and as discussed above, the choice of seagrass isotope values for the value of $\delta^{13} \mathrm{C}_{\mathrm{OM}}$ used in calculating $\delta^{13} C_{\text {added }}^{\text {pred }}$ leads to an upper limit in its value. As a result, the positive values of DRI we see in the sediments would only become more positive if in our calculations we assumed that some amount of non-seagrass (that is, isotopically lighter) carbon was also undergoing remineralization in these sediments. As a general observation, we also note that this would be true for seagrass-containing sites (that is, $L A I>0$ ) if non-seagrass plus seagrass organic matter were undergoing remineralization in these sediments as well.

In the group 2 sediments, the similarity in the values of $\delta^{13} C_{\text {added }}^{\text {pred }}$ and $\delta^{13} C_{\text {added }}^{p w}$ (that is, $D R I \approx 0$ ) is consistent with a seagrass carbon source for the organic matter undergoing remineralization in these sediments, though in the absence here of coupled dissolution/reprecipitation. Interestingly however, the group 2 sediments included site 25, where very high seagrass densities were observed. This observation appears to contradict our previous findings in Lee Stocking Island sediments where we observed carbonate dissolution/reprecipitation only in densely vegetated (high $L A I$ ) sediments ( $\mathrm{Hu}$ and Burdige, 2007). Furthermore, the pore water modeling results discussed in the previous section also suggest the possible occurrence of dissolution/ reprecipitation in sites 25 and 24 sediments (another group 2 sediment; model results not available for the other group 2 sediments, sites 16 and 17). To potentially reconcile these contradictory observations, we note that if reprecipitation does occur at all of these group 2 sites, then some amount of isotopically lighter organic carbon (for example, algal carbon) may also be remineralized in addition to seagrass material, to counter the heavy carbon being added to the pore waters by dissolution and reprecipitation.

The group 3 sediments are very low-to-intermediate density seagrass sites, where the observed negative $D R I$ values imply that seagrass carbon plus some amount of isotopically light organic matter (for example, benthic algal carbon or phytoplankton debris) must be undergoing remineralization, regardless of whether or not dissolution/ reprecipitation is also occurring. Consistent with this suggestion is the fact that the sediments at two of these sites were among the coarsest of all of the study sites (table 1), allowing for the possible advective input of small, suspended particles (for example, phytoplankton debris) into the sediments (Huettel and Rusch, 2000). Given these three potential types of organic matter that may contribute to the material undergoing remineralization in these sediments, and the wide range of their $\delta^{13} \mathrm{C}$ values, a predicted value of $\delta^{13} \mathrm{C}_{\mathrm{OM}}$ in these sediments is essentially unconstrained. It is 
therefore not possible to use the isotope mixing model (that is, eq. 8) and the calculation of DRI in the manner described here to look for isotopic evidence of coupled dissolution/reprecipitation in these group 3 sediments.

One immediate conclusion that comes from this analysis is that across the broad expanse of the Bahamas Bank it may not always be appropriate to assume that seagrass organic carbon is the sole carbon source being remineralized in the sediments. Thus the stable isotope mass balance approach used here to examine carbonate dissolution and reprecipitation should be used with caution. While pore water modeling provides some further constraints on this problem, it too has limitations (particularly at low rates of sediment carbonate dissolution). Future studies of compound-specific stable isotope in bacterial lipids (Holmer and others, 2001; Jones and others, 2003) could, however, provide more specific information on the $\delta^{13} \mathrm{C}$ of the organic matter being remineralized in these sediments, and thus help to better constrain these stable isotope mass balance calculations.

At the same time, despite this limitation of the stable isotope mass balance approach, we see relatively "heavy" values of $\delta^{13} C_{\text {added }}^{\text {pred }}$ (or equivalently, positive DRI values) at more than half of the sites we have studied, across a range of $L A I$ values. These results provide further evidence, complimenting the pore water results presented in the previous section, for the widespread occurrence of carbonate dissolution/ reprecipitation across much of the Bahamas Bank.

\section{Factors Controlling Carbonate Dissolution/Reprecipitation in GBB Sediments}

In our earlier work examining carbonate dissolution and reprecipitation in Lee Stocking Island sediments (Hu and Burdige, 2007), we noted that stable isotope mass balance calculations showed evidence of this coupled process only in sediments at dense seagrass sites ( $L A I$ values of $\sim 1.4$ ). However based on the results presented here, along with those from our recent sediment incubations studies ( $\mathrm{Hu}$ and Burdige, 2008), we now have a slightly different picture of the controls on dissolution/ reprecipitation. In particular, we see that at sites where the interpretation of stable isotope results are unambiguous regarding the occurrence of dissolution/reprecipitation (that is, the group 1 sediments where $D R I>0$ ) $L A I$ values range from 0 to 2.2 (fig. 11).

These new results therefore suggest that seagrass density alone does not control the occurrence of carbonate dissolution/precipitation. However, the results in figure 11 do show that DRI becomes more positive as sediment grain size decreases. Expressed another way, it appears that the reprecipitation process, which contributes heavy DIC to the pore waters, becomes more evident in finer-grained sediments. This observation is consistent with an Ostwald ripening process, in which smaller grains preferentially dissolve and secondary carbonates form on larger grains (Walter and others, 1993; Reid and Macintyre, 1998; Hover and others, 2001).

In light of this relationship between $D R I$ and grain size in Bahamas Bank sediments, it is now also somewhat more puzzling as to why DRI and LAI show no correlation (which would be consistent with the results from the Lee Stocking Island sites discussed above), since in many settings seagrasses tend to preferentially trap fine-grained sediments (for example, Morse and others, 1987; Koch and others, 2006). However, we only observed a weak inverse relationship between log (mean grain size) and $L A I\left(r^{2}=0.18, p<0.05\right)$ in the Bahamas Bank sediments of this study $(\mathrm{Hu}, \mathrm{ms}$, 2007), and, for example, sediments on the northwest side of Andros Island (where whiting events are often observed; Morse and others, 2003) have small mean grain sizes, higher percentages of fine-grained materials (defined here as grain size $<63$ $\mu \mathrm{m}$ ), and $L A I$ values $\sim 0$ (table 1$)$.

These results therefore suggest that linkages between sediment grain size and $L A I$ in carbonate platform sediments are complex, and as a result, multiple factors likely 
control the occurrence of coupled dissolution and reprecipitation even beyond these two parameters (for example, see analogous discussions in the Sediment-seagrass interactions and sediment carbonate dissolution section). These other possible controlling factors include sediment mineralogy (for example, aragonite vs. HMC), sediment type (for example, ooid vs. skeletal sands), or sediment permeability (see similar discussions in Walter and others, 2007).

Based on the pore water modeling results, we see that reprecipitation roughly increases in a linear fashion with net dissolution (that is, $R_{\mathrm{rx}}$ is a constant value). This observation supports suggestions made earlier (Hu and Burdige, 2007) that metabolic carbonate dissolution may create new nucleation sites for heterogeneous precipitation and/or "cleanse" existing sites on the carbonate grain surfaces of substances that inhibit precipitation (for example, phosphate or dissolved organic matter; Berner and others, 1978; Morse and Mucci, 1984; Mucci, 1987). Either of these could then explain how net dissolution also facilitates reprecipitation.

Finally, the fact that dissolution/reprecipitation is independent of $L A I$ implies that seagrasses themselves do not directly lead to the occurrence of the coupled process. Rather, any process, or set of environmental conditions, that enhances dissolution (through, for example, acid addition or production) in shallow water carbonate sediments should also lead to the occurrence of coupled dissolution/ precipitation.

IMPLICATIONS OF THESE RESULTS ON SHALLOW WATER CARBONATE SEDIMENT DIAGENESIS

The results presented here demonstrate that carbonate dissolution and reprecipitation is a widespread phenomenon in the shallow water carbonate sediments on the Bahamas Bank. The sites where we have observed these coupled processes span a wide range of seagrass densities and sediment types (for example, ooid sands, pellet muds and grapestones); equally important, dissolution/reprecipitation appears to occur on early diagenetic time scales ( $\mathrm{Hu}$ and Burdige, 2008). Past studies have shown the importance of dissolution/reprecipitation in more organic-"rich" carbonate sediments (for example, Rude and Aller, 1991; Ku and others, 1999; Walter and others, 2007), and the results shown here expand this observation to the more organic-"poor" sediments that are more commonly found on shallow water carbonate platforms. The work discussed here has also primarily focused on the occurrence of dissolution and reprecipitation during the post-depositional early diagenesis of shallow water carbonate sediments. However, these observations also provide mechanistic insights into the processes that may lead to the formation of carbonate cements and micrites at the sediment surface and on, for example, carbonate hardgrounds.

In our previous work (Burdige and others, 2008) we coupled a remote sensing analysis of seagrass distribution on the Bahamas Bank (Dierssen and others, 2010) and a relationship similar to that shown in figure 7 (but based solely on Lee Stocking Island results) to estimate the aerially-integrated dissolution flux on the Bahamas Bank of $\sim 9$ $\mathrm{mmol} \cdot \mathrm{m}^{-2} \cdot \mathrm{d}^{-1}$. Using the same approach here with the relationship in figure 7 (which includes our earlier results as well as the results presented here from a wider range of sediments across a larger expanse of the Bahamas Bank) we obtain a similar, but slightly lower integrated dissolution flux, $7.8( \pm 4.5) \mathrm{mmol} \cdot \mathrm{m}^{-2} \cdot \mathrm{d}^{-1}$. Both our current (and previous) values for the dissolution flux are comparable to Milliman's (1993) estimates of the gross carbonate production flux $\left(13.7 \mathrm{mmol} \cdot \mathrm{m}^{-2} \cdot \mathrm{d}^{-1}\right)$, or the net accumulation or offshore carbonate export fluxes (both estimated at 6.8 $\left.\mathrm{mmol} \cdot \mathrm{m}^{-2} \cdot \mathrm{d}^{-1}\right)$. Carbonate dissolution is therefore an important loss term in the budget of shallow water carbonate sediments, and on-bank carbonate dissolution, rather than offshore transport, may represent an important sink for gross shallow water carbonate production (also see discussions in Yates and Halley, 2006; Walter and others, 2007; Burdige and others, 2008). This dissolution may also play some role in 
explaining the upper water column alkalinity halo observed around many carbonate platforms (Sabine and Mackenzie, 1995).

If this dissolution flux is scaled up over the $\sim 800,000 \mathrm{~km}^{2}$ area of carbonate bank and bay sediments globally (Milliman, 1993), this translates into a global shallow-water bank and bay sediments dissolution rate of $\sim 0.03 \mathrm{Pg} \mathrm{PIC} \cdot \mathrm{yr}^{-1}$. As noted in Burdige and others (2008) this value agrees well with a physical-biogeochemical box model estimate (Andersson and others, 2003) of carbonate dissolution for all shallowwater sediments $\left(0.13 \mathrm{Pg} \mathrm{PIC} \cdot \mathrm{yr}^{-1}\right)$, when one takes into account the fact that shallow-water carbonate bank and bay sediments represent only $\sim 28$ percent of all shallow-water sediments.

Of equal importance is the fact that these shallow water carbonate dissolution rates are of a similar magnitude to several important terms in the oceanic alkalinity/ $\mathrm{CaCO}_{3}$ budget, including: the alkalinity riverine input derived from weathering (dissolution) of calcium carbonate on land, $0.2 \mathrm{Pg} \mathrm{PIC} \cdot \mathrm{yr}^{-1}$ (Mackenzie and others, 2004); the mid-water (200-1500 m) dissolution rate from all three ocean basins, $1.0 \mathrm{Pg}$ $\mathrm{PIC} \cdot \mathrm{yr}^{-1}$ (Berelson and others, 2007); model-estimates of the $\mathrm{CaCO}_{3}$ export flux from the surface ocean, 0.4-1.8 $\mathrm{Pg} \mathrm{PIC} \cdot \mathrm{yr}^{-1}$ (Berelson and others, 2007). Recent studies have also illustrated some of the uncertainties in our knowledge of the sources and sinks of alkalinity to the surface (upper $\sim 100 \mathrm{~m}$ ) of the global ocean, particularly from carbonate banks and bays (for example, Milliman and Droxler, 1996; Wright and Cherns, 2004; James and others, 2005), and continental margins in general regions (Chen, 2002; Berelson and others, 2007). Given these observations, the results presented here further suggest that shallow water carbonate dissolution may also be important in the alkalinity dynamics of surface ocean waters, and should be more carefully considered in alkalinity budgets for surface ocean waters.

Because of the apparent importance of carbonate dissolution in the dynamics of shallow water carbonate sediments, the observation that reprecipitation rates are of the same order as dissolution rates $\left(R_{\mathrm{rx}} \geq 1\right.$ based on the results presented here, as well as other results in the literature; see table 4 ) takes on added significance. Coupled dissolution/reprecipitation can have a major impact on the stable isotopic composition of sediment carbonates (Rude and Aller, 1991; Patterson and Walter, 1994), and, for example, can be thought of as a process in which "primary" sedimentary carbonate carbon (with a $\delta^{13} \mathrm{C}$ value that is generally $\geq 0 \%$ ) is partially "exchanged" with carbonate derived from organic carbon (with a $\delta^{13} \mathrm{C}$ value that is $<0 \%$ ) that has been added to the pore water DIC pool by organic matter remineralization (Walter and others, 2007). Over time, this process should lead to lower (more negative) isotopic values of the bulk sedimentary carbonate, and if the extent of recrystallization is large (as the calculations here suggest they may be), the isotopic signature of shallow water carbonates is likely to have a significant diagenetic overprint.

The $\delta^{13} \mathrm{C}$ of carbonate sediments and sedimentary rocks has been used in examining many aspects of the global carbon cycle both in the present and throughout geologic time (Kump and Arthur, 1999; Berner, 2004; Swart, 2008). For example, the difference between the $\delta^{13} \mathrm{C}$ of organic carbon and carbonate carbon in both ancient sediments and sedimentary rocks may provide important information on changes through time in the burial of organic matter in sediments (also see Hayes and others, 1999).

In the modern ocean roughly 40 percent of carbonate burial occurs in shallow water (versus pelagic) sediments (Milliman, 1993). However throughout much of the Phanerozoic shallow water carbonates were likely more important sites of carbonate deposition and burial than they are today (Berner, 2004). In part this is due to a substantial decrease over this time period in the area of carbonate shelf sediments (Mackenzie and Morse, 1992; Walker and others, 2002), and in part because the 
evolution and appearance of calcareous nannoplankton such as coccoliths, which represent the predominant source of deep-water carbonate sediments, did not occur until the late Triassic, $\sim 225 \mathrm{Ma}$ (Bown and others, 2004). Thus, the extent to which carbonate dissolution/reprecipitation processes alter the "primary" isotopic signature of shallow water carbonates-before they are buried in more diagenetically stable environments such as periplatform sediments (for example, Swart, 2008), or become incorporated into the rock record-has the potential to compromise the information these isotope records may provide on the past operation of the global carbon cycle (see similar discussions in Walter and others, 2007). Furthermore, since dissolution/ reprecipitation does not specifically require the presence of seagrasses, the fact that seagrasses evolved only $\sim 100 \mathrm{Ma}$ (Hemminga and Duarte, 2000) does not impact the possible importance of dissolution/reprecipitation over geologic time.

\section{CONCLUSIONS}

1. Pore water modeling results and the results from stable isotope mass balance calculations provide independent and complimentary information on the widespread occurrence of carbonate dissolution/reprecipitation across a broad range of sediments on the Bahamas Bank.

2. The input of oxygen into the sediments, which ultimately controls sediment carbonate dissolution, has two major sources-belowground input by seagrasses (that is, seagrass $\mathrm{O}_{2}$ pumping), and permeability-driven advective pore water exchange. The relative importance of these $\mathrm{O}_{2}$ delivery mechanisms depends in part on seagrass density. However it also depends on how bottom water flow interacts with the seagrass canopy and leads to this advective exchange.

3. Dissolution appears to involve the preferential dissolution of high-Mg calcite, and the rates of dissolution increase linearly with increasing seagrass density.

4. The rate of reprecipitation is a near constant ratio of the rates of both total and net dissolution. The reprecipitation ratio (reprecipitation rate divided by net dissolution rate) estimated from our pore water modeling is $\sim 1.3$ to 3.8 and is similar to estimates of this ratio from other sites obtained using a number of different analytical and modeling techniques.

5. Isotopic evidence of dissolution/reprecipitation is independent of seagrass density, but does appear to be inversely related to mean sediment grain size. This last observation is consistent with the occurrence of Ostwald ripening as the mechanism of reprecipitation, in which smaller crystals dissolve and then reprecipitate as larger crystals, with little or no change in mineralogy.

6. Coupling the observed relationship between carbonate dissolution rates and seagrass density with a remote sensing analysis of seagrass distribution on the Bahamas Bank allows us to estimate the aerially-integrated dissolution flux on the Bank $(\sim 7.9$ $\left.\mathrm{mmol} \cdot \mathrm{m}^{-2} \cdot \mathrm{d}^{-1}\right)$. This estimate is comparable to both the gross carbonate production flux $\left(13.7 \mathrm{mmol} \cdot \mathrm{m}^{-2} \cdot \mathrm{d}^{-1}\right)$ as well as the net accumulation or offshore carbonate export fluxes (both estimated at $6.8 \mathrm{mmol} \cdot \mathrm{m}^{-2} \cdot \mathrm{d}^{-1}$ ). Carbonate dissolution is therefore an important loss term in the budget of shallow water carbonate sediments, and on-bank carbonate dissolution, rather than offshore transport, may represent an important sink for gross shallow water carbonate production.

7. Dissolution in carbonate bank and bay sediments may also be of some importance as an alkalinity source to the upper $100 \mathrm{~m}$ of the global ocean, and should be considered in global alkalinity/carbonate budget.

8. Reprecipitation rates are of the same order as dissolution rates $\left(R_{\mathrm{rx}} \geq 1\right)$, implying that carbonate reprecipitation is similarly important in the dynamics of shallow water carbonate sediments. Coupled dissolution/reprecipitation may therefore have a major impact on the stable isotope composition of carbonate sediments that are ultimately preserved in the rock record. These observations need to be 
considered, for example, when using carbon isotope records to obtain information on the operation of the global carbon cycle during the Phanerozoic.

\section{ACKNOWLEDGMENTS}

This work was supported by grants from the US National Science Foundation (Chemical Oceanography Program). For assistance in the field and in the lab we thank: Heidi Dierssen (University of Connecticut); Fritz Neuweiler (Laval University); Kim Krecek, Michelle McElvaine, Scott Kline, Kip Gardner, Jean-Paul Simjouw, Lisa Drake (all formally at ODU); and Laura Bodensteiner (MLML). Heidi Dierssen also provided important assistance in the calculation of regional carbonate dissolution budgets. We thank David Archer and Fred Mackenzie for thoughtful reviews of the first version of this paper. Finally we thank the captain and crew of the R/V Walton Smith for the smooth operation of the ship during our cruise.

\section{REFERENCES}

Andersson, A. J., Mackenzie, F. T., and Ver, L. M., 2003, Solution of shallow-water carbonates: An insignificant buffer against rising atmospheric $\mathrm{CO}_{2}$ : Geology, v. 31, p. 513-516, doi: 10.1130/00917613(2003) 031<0513:SOSCAI>2.0.CO;2.

Andersson, A. J., Bates, N. R., and Mackenzie, F. T., 2007, Dissolution of carbonate sediments under rising $p \mathrm{CO}_{2}$ and ocean acidification: Observations from Devil's Hole, Bermuda: Aquatic Geochemistry, v. 13, p. 237-264, doi: 10.1007/s10498-007-9018-8.

Barth, N. G., 1984, Modern Methods of Particle Size Analysis: New Jersey, John Wiley and Sons, 320 p.

Bathurst, R. G. C., 1974, Marine diagenesis of shallow water calcium carbonate sediments: Annual Review of Earth and Planetary Sciences, v. 2, p. 257-274, doi: 10.1146/annurev.ea.02.050174.001353.

Berelson, W. M., Balch, W. M., Najjar, R., Feely, R. A., Sabine, C., and Lee, K., 2007, Relating estimates of $\mathrm{CaCO}_{3}$ production, export, and dissolution in the water column to measurements of $\mathrm{CaCO}_{3}$ rain into sediment traps and dissolution on the sea floor: A revised global carbonate budget: Global Biogeochemal Cycles, v. 21, GB1024, doi: 10.1029/2006GB002803.

Berner, R. A., 1966, Chemical diagenesis of some modern carbonate sediments: Amercian Journal of Science, v. 264, p. 1-36.

- 1975, The role of magnesium in the crystal growth of calcite and aragonite from sea water: Geochimica et Cosmochimica Acta, v. 39, p. 489-494, doi: 10.1016/0016-7037(75)90102-7.

— 1977, Stoichiometric models for nutrient regeneration in anoxic sediments: Limnology and Oceanography, v. 22, p. 781-786, doi: 10.4319/1o.1977.22.5.0781.

2004, The Phanerozoic Carbon Cycle: $\mathrm{CO}_{2}$ and $\mathrm{O}_{2}$ : Oxford, Oxford University Press, $158 \mathrm{p}$.

Berner, R. A., Westrich, J. T., Graber, R., Smith, J., and Martens, C. S., 1978, Inhibition of aragonite precipitation from supersaturated seawater: a laboratory and field study: American Journal of Science, v. 278 , p. $816-837$.

Bischoff, W. D., Bertram, M. A., Mackenzie, F. T., and Bishop, F. C., 1993, Diagenetic stabilization pathways of magnesian calcites: Carbonates and Evaporites, v. 8, p. 82-89, doi: 10.1007/BF03175165.

Bodensteiner, L. E., ms, 2006, The Impact of Light Availability on Benthic Oxygen Release by the Seagrasses Thalassia testudinum (Banks ex Koenig) and Zostera marina: San Jose, California, San Jose State University, Master's Thesis, 37 p.

Boschker, H. T. S., Wielemaker, A., Schaub, B. E. M., and Holmer, M., 2000, Limited coupling of macrophyte production and bacterial carbon cycling in the sediments of Zostera spp. meadows: Marine Ecology Progress Series, v. 203, p. 181-189, doi: 10.3354/meps203181.

Boudreau, B. P., Huettel, M., Forster, S., Jahnke, R. A., McLachlan, A., Middelburg, J. J., Nielsen, P., Sansone, F., Taghon, G., Van Raaphorst, W., Webster, I., Marcin, J., Wiberg, P., and Sundby, B., 2001, Permeable marine sediments, overturning an old paradigm: Eos Transactions of the American Geophysical Union, v. 82 , p. $133-136$.

Bouillon, S., and Boschker, H. T. S., 2006, Bacterial carbon sources in coastal sediments: a cross-system analysis based on stable isotope data of biomarkers: Biogeosciences, v. 3, p. 175-185, doi: 10.5194/bg-3$175-2006$.

Bown, P. R., Lees, J. A., and Young, J. R., 2004, Calcareous nannoplankton evolution and diversity through time, in Thierstein, H. R., and Young, J. R., editors, Coccolithophores: From Molecular Processes to Global Impact: Berlin, Springer, p. 481-500.

Burdige, D. J., 2006, Geochemistry of Marine Sediments: Princeton, Princeton University Press, 630 p.

Burdige, D. J., and Zimmerman, R. C., 2002, Impact of seagrass density on carbonate dissolution in Bahamian sediments: Limnology and Oceanography, v. 47, p. 1751-1763, doi: 10.4319/lo.2002.47.6.1751.

Burdige, D. J., Zimmerman, R. C., and Hu, X., 2008, Rates of carbonate dissolution in permeable sediments estimated from pore water profiles: The role of seagrasses: Limnology and Oceanography, v. 53, n. 2, p. $549-565$.

Chen, C.-T. A., 2002, Shelf- vs. dissolution-generated alkalinity above the chemical lysocline: Deep-Sea Research II, v. 49, p. 5365-5375, doi: 10.1016/S0967-0645(02)00196-0. 
Cline, J. D., 1969, Spectrophotometric determination of hydrogen sulfide in natural waters: Limnology and Oceanography, v. 14, p. 454-458, doi: 10.4319/lo.1969.14.3.0454.

Craig, H., 1953, The geochemistry of the stable carbon isotopes: Geochimica et Cosmochimica Acta, v. 3, p. 53-92, doi: 10.1016/0016-7037(53)90001-5.

Dickson, A. G., Afghan, J. D., and Anderson, G. C., 2003, Reference materials for oceanic $\mathrm{CO}_{2}$ analysis: a method for the certification of total alkalinity: Marine Chemistry, v. 80, p. 185-197, doi: 10.1016/S03044203(02) 00133-0.

Dickson, A. G., Sabine, C. L., and Christian, J. R., 2007, Guide to Best Practices for Ocean $\mathrm{CO}_{2}$ Measure- $^{-}$ ments: PICES Special Publication 3, p. 191.

Dierssen, H. M., Zimmerman, R. C., and Burdige, D. J., 2009a, Optics and remote sensing of Bahamian carbonate sediment whitings and potential relationship to wind-driven Langmuir circulation: Biogeosciences, v. 6, p. 487-500, doi: 10.5194/bg-6-487-2009.

Dierssen, H. M., Zimmerman, R. C., Drake, L. A., and Burdige, D. J., 2009b, Potential export of unattached benthic macroalgae to the deep sea through wind-driven Langmuir circulation: Geophysical Research Letters, v. 36, p. L04602, doi: 10.1029/2008GL036188.

_ 2010, Benthic ecology from space: optics and net primary production across the Great Bahama Bank from seagrass and benthic algae: Marine Ecology Progress Series, doi: 10.3354/meps08665.

Fourqurean, J. W., Escorcia, S. P., Anderson, W. T., and Zieman, J. C., 2005, Spatial and seasonal variability in elemental content, $\delta^{13} \mathrm{C}$, and $\delta^{15} \mathrm{~N}$ of Thalassia testudinum from South Florida and its implications for ecosystem studies: Estuaries and Coasts, v. 28, p. 447-461, doi: 10.1007/BF02693926.

Hammond, D. E., Giordani, P., Berelson, W. M., and Poletti, R., 1999, Diagenesis of carbon and nutrients and benthic exchange in sediments of the Northern Adriatic Sea: Marine Chemistry, v. 66, p. $53-97$, doi: 10.1016/S0304-4203(99)00024-9.

Hayes, J. M., Strauss, H., and Kaufman, A. J., 1999, The abundance of ${ }^{13} \mathrm{C}$ in marine organic matter and isotopic fractionation in the global biogeochemical cycle of carbon during the past $800 \mathrm{Ma}$ : Chemical Geology, v. 161, p. 103-125, doi: 10.1016/S0009-2541(99)00083-2.

Hemminga, M. A., and Duarte, C. M., 2000, Seagrass Ecology: Cambridge, Cambridge University Press, $298 \mathrm{p}$.

Hemminga, M. A., and Mateo, M. A., 1996, Stable carbon isotopes in seagrasses: variability in ratios and use in ecological studies: Marine Ecology Progress Series, v. 140, p. 285-298, doi: 10.3354/meps140285.

Hofmann, M., Wolf-Gladrow, D. A., Takahashi, T., Sutherland, S. C., Six, K. D., and Maier-Reimer, E., 2000, Stable carbon isotope distribution of particulate organic matter in the ocean: a model study: Marine Chemistry, v. 72, p. 131-150, doi: 10.1016/S0304-4203(00)00078-5.

Holmer, M., Andersen, F. Ø., Nielsen, S. L., and Boschker, H. T. S., 2001, The importance of mineralization based on sulfate reduction for nutrient regeneration in tropical seagrass sediments: Aquatic Botany, v. 71, p. 1-17, doi: 10.1016/S0304-3770(01)00170-X.

Hover, V. C., Walter, L. M., and Peacor, D. R., 2001, Early marine diagenesis of biogenic aragonite and Mg-calcite: new constraints from high-resolution STEM and AEM analyses of modern platform carbonates: Chemical Geology, v. 175, p. 221-248, doi: 10.1016/S0009-2541(00)00326-0.

$\mathrm{Hu}$, X., ms, 2007, Seagrass-Mediated Carbonate Dissolution and Early Diagenesis in Bahamas Bank Sediments: Norfolk, Virginia, Old Dominion University, Ph. D. dissertation, p. 201.

$\mathrm{Hu}, \mathrm{X}$., and Burdige, D. J., 2007, Enriched stable carbon isotopes in the pore waters of carbonate sediments dominated by seagrasses: Evidence for coupled carbonate dissolution and reprecipitation: Geochimica et Cosmochimica Acta, v. 71, p. 129-144, doi: 10.1016/j.gca.2006.08.043.

— 2008, Shallow marine carbonate dissolution and early diagenesis-Implications from an incubation study: Journal of Marine Research, v. 66, p. 489-527, doi: 10.1357/002224008787157449.

$\mathrm{Hu}$, X., Burdige, D. J., and Zimmerman, R. C., 2009, Light controls carbon isotope signatures of turtlegrass across the Great Bahamas Bank: Presented at the Coastal and Estuarine Research Federation 20th Biennial Conference, Portland, Oregon.

Huettel, M., and Rusch, A., 2000, Transport and degradation of phytoplankton in permeable sediment: Limnology and Oceanography, v. 45, p. 534-549, doi: 10.4319/1o.2000.45.3.0534.

Huettel, M., and Webster, I. T., 2001, Porewater flow in permeable sediments, in Boudreau, B. P., and Jørgensen, B. B., editors, The Benthic Boundary Layer: Oxford, Oxford University Press, p. 144-179.

James, N. P., Bone, Y., and Kyser, T. K., 2005, Where has all the aragonite gone? Mineralogy of Holocene neritic cool-water carbonates, Southern Australia: Journal of Sedimentary Research, v. 75, p. 454-463, doi: 10.2110/jsr.2005.035.

Jones, W. B., Cifuentes, L. A., and Kaldy, J. E., 2003, Stable carbon isotope evidence for coupling between sedimentary bacteria and seagrasses in a sub-tropical lagoon: Marine Ecology Progress Series, v. 255, p. 15-25, doi: 10.3354/meps255015.

Koch, E. W., and Gust, G., 1999, Water flow in tide- and wave-dominated beds of the seagrass Thalassia testudinum: Marine Ecology Progress Series, v. 184, p. 63-72, doi: 10.3354/meps184063.

Koch, E. W., Ackerman, J. D., Verduin, J., and van Keulen, M., 2006, Fluid dynamics in seagrass ecologyfrom molecules to ecosystems, in Larkum, A. W. D., Orth, R. J., and Duarte, C., editors, Seagrasses: Biology, Ecology and Conservation: Dordrecht, The Netherlands, Springer, p. 193-225.

Ku, T. C. W., Walter, L. M., Coleman, M. L., Blake, R. E., and Martini, A. M., 1999, Coupling between sulfur recycling and syndepositional carbonate dissolution: Evidence from oxygen and sulfur isotope compositions of pore water sulfate, South Florida Platform, U.S.A: Geochimica et Cosmochimica Acta, v. 63 , p. 2529-2546, doi: 10.1016/S0016-7037(99)00115-5.

Kump, L. R., and Arthur, M. A., 1999, Interpreting carbon-isotope excursions: carbonates and organic matter: Chemical Geology, v. 161, p. 181-198, doi: 10.1016/S0009-2541(99)00086-8.

Lewis, E., and Wallace, D. W. R., 1998, Program developed for $\mathrm{CO}_{2}$ system calculations: Oak Ridge, 
Tennessee, Oak Ridge National Laboratory, Carbon Dioxide Information Analysis center, U.S. Department of Energy, ORNL/CDIAC-105.

Mackenzie, F. T., and Morse, J. W., 1992, Sedimentary carbonates through Phanerozoic time: Geochimica et Cosmochimica Acta, v. 56, p. 3281-3295, doi: 10.1016/0016-7037(92)90305-3.

Mackenzie, F. T., Lerman, A., and Andersson, A. J., 2004, Past and present of sediment and carbon biogeochemical cycling models: Biogeosciences, v. 1, p. 11-32, doi: 10.5194/bg-1-11-2004.

Melim, L. A., Westphal, H., Swart, P. K., Eberli, G. P., and Munnecke, A., 2002, Questioning carbonate diagenetic paradigms: evidence from the Neogene of the Bahamas: Marine Geology, v. 185, p. 27-53, doi: 10.1016/S0025-3227(01)00289-4.

Milliman, J. D., 1974, Marine Carbonates: Berlin, Springer-Verlag, 375 p.

— 1993, Production and accumulation of calcium carbonate in the ocean: Budget of a nonsteady state: Global Biogeochemical Cycles, v. 7, p. 927-957, doi: 10.1029/93GB02524.

Milliman, J. D., and Droxler, A. W., 1996, Neritic and pelagic carbonate sedimentation in the marine environment: ignorance is not bliss: Geolische Rundschau, v. 85, p. 496-504, doi: 10.1007/ BF02369004.

Mook, W. G., and De Vries, J. J., 2001, Environmental Isotopes in the Hydrological Cycle: Principles and Applications. Volume I: Introduction-Theory, Methods, Review: Paris, UNESCO/IAEA, 280 p.

Morse, J. W., 2003, Formation and diagenesis of carbonate sediments, in Mackenzie, F. T., editor, Sediments, Diagenesis, and Sedimentary Rocks: Treatise on Geochemistry, v. 7, p. 67-85, doi: 10.1016/B0-08-0437516/07093-6doi: 10.1016/B0-08-043751-6/07093-6.

Morse, J. W., and Casey, W. H., 1988, Ostwald processes and mineral paragenesis in sediments: American Journal of Science, v. 288, p. 537-560.

Morse, J. W., and Mackenzie, F. T., 1990, Geochemistry of Sedimentary Carbonates: Amsterdam, Elsevier, Developments in Sedimentology 48, $696 \mathrm{p}$.

Morse, J. W., and Mucci, A., 1984, Composition of carbonate overgrowths produced on Iceland spar calcite crystals buried in Bahamian carbonate-rich sediments: Sedimentary Geology, v. 40, p. 287-291, doi: 10.1016/0037-0738(84)90012-5.

Morse, J. W., Zulllig, J. J., Bernstein, L. D., Millero, F. J., Milne, P. J., Mucci, A., and Choppin, G. R., 1985, Chemistry of calcium carbonate-rich shallow water sediments in the Bahamas: American Journal of Science, v. 285, p. 147-185.

Morse, J. W., Zullig, J. J., Iverson, R. L., Choppin, G. R., Mucci, A., and Millero, F. J., 1987, The influence of seagrass beds on carbonate sediments in the Bahamas: Marine Chemistry, v. 22, p. 71-83, doi: 10.1016/0304-4203(87)90049-1.

Morse, J. W., Gledhill, D. K., and Millero, F. J., 2003, $\mathrm{CaCO}_{3}$ precipitation kinetics in waters from the Great Bahama Bank: Implications for the relationship between Bank hydrochemistry and whitings: Geochimica et Cosmochimica Acta, v. 67, p. 2819-2862, doi: 10.1016/S0016-7037(03)00103-0.

Morse, J. W., Andersson, A. J., and Mackenzie, F. T., 2006, Initial responses of carbonate-rich shelf sediments to rising atmospheric $p \mathrm{CO}_{2}$ and "ocean acidification": Role of high Mg-calcites: Geochimica et Cosmochimica Acta, v. 70, p. 5814-5830, doi: 10.1016/j.gca.2006.08.017.

Moulin, E., Jordens, A., and Wollast, R., 1985, Influence of the aerobic bacterial respiration on the early dissolution of carbonates in coastal sediments, in Van Grieken, R., and Wollast, R., editors, Progress in Belgian Oceanographic Research: Brussels, Belgium, March 3-5, 1985, Proceedings of a Symposium held at the Palace of Academies Brussels, Brussels, p. 196-205.

Mucci, A., 1983, The solubility of calcite and aragonite in seawater at various salinities: American Journal of Science, v. 283, p. 780-799.

— 1986, Growth kinetics and composition of magnesian calcite overgrowths precipitated from seawater: Quantitative influence of orthophosphate ions: Geochimica et Cosmochimica Acta, v. 50, p. 2255-2265, doi: 10.1016/0016-7037(86)90080-3.

_ 1987, Influence of temperature on the composition of magnesian calcite overgrowths precipitated from seawater: Geochimica et Cosmochimica Acta, v. 51, p. 1977-1984, doi: 10.1016/00167037(87)90186-4.

Patterson, W. P., and Walter, L. M., 1994, Sydepositional diagenesis of modern platform carbonates: Evidence from isotopic and minor element data: Geology, v. 22, p. 127-130, doi: 10.1130/00917613(1994)022<0127:SDOMPC > 2.3.CO;2.

Purdy, E. G., 1968, Carbonate diagenesis: an environmental survey: Geologica Romana, v. VII, p. 183-228.

Rasmussen, K. A., Haddad, R. I., and Neumann, A. C., 1990, Stable-isotope record of organic carbon from an evolving carbonate banktop, Bight of Abaco, Bahamas: Geology, v. 18, p. 790-794, doi: 10.1130/00917613(1990) 018<0790:SIROOC >2.3.CO;2.

Reid, R. P., and Macintyre, I. G., 1998, Carbonate recrystallization in shallow marine environments: a widespread diagenetic process forming micritized grains: Journal of Sedimentary Research, v. 68, p. $928-946$.

2000, Microboring versus recrystallization: further insight into the micritization process: Journal of Sedimentary Research, v. 70, p. 24-28, doi: 10.1306/2DC408FA-0E47-11D7-8643000102C1865D.

Rude, P. D., and Aller, R. C., 1991, Fluorine mobility during early diagenesis of carbonate sediments: An indicator of mineral transformations: Geochimica et Cosmochimica Acta, v. 55, p. 2491-2509, doi: 10.1016/0016-7037(91)90368-F.

Sabine, C. L., and Mackenzie, F. T., 1995, Bank-Derived Carbonate Sediment Transport and Dissolution in the Hawaiian Archipelago: Aquatic Geochemistry, v. 1, p. 188-230, doi: 10.1007/BF00702891.

Sayles, F. L., and Curry, W. B., 1988, $\delta^{13} \mathrm{C}, \mathrm{TCO}_{2}$ and the metabolism of organic carbon in deep sea sediments: Geochimica et Cosmochimica Acta, v. 52, p. 2963-2978, doi: 10.1016/0016-7037(88)90161-5.

Scalan, R. S., and Morgan, T. D., 1970, Isotope ratio mass spectrometer instrumentation and application to 
organic matter contained in recent sediments: International Journal of Mass Spectrometry and Ion Physics, v. 4, p. 267-281, doi: 10.1016/0020-7381(70)85043-4.

Swart, P. K., 2008, Global synchronous changes in the carbon isotopic composition of carbonate sediments unrelated to changes in the global carbon cycle: Proceedings of the National Academy of Sciences, v. 105, p. 13741-13745, doi: 10.1073/pnas.0802841105.

Swart, P. K., Reijmer, J. J. G., and Otto, R., 2009, A reevaluation of facies on Great Bahama Bank II: Variations in $\delta^{13} \mathrm{C}, \delta^{18} \mathrm{O}$ and mineralogy of surface sediments, in Swart, P. K., Eberli, G. P., and Mackenzie, J. A., editors, Perspectives in Carbonate Geology: A Tribute To The Career Of Robert Nathan Ginsburg: Oxford, Wiley-Blackwell, International Association of Sedimentologists Special Publication, v. 41, p. $47-59$.

Tribble, J. S., and Mackenzie, F. T., 1998, Recrystallization of magnesian calcite overgrowths on calcite seeds suspended in seawater: Aquatic Geochemistry, v. 4, p. 337-360, doi: 10.1023/A:1009636331784.

Walker, L. J., Wilkinson, B. H., and Ivany, L. C., 2002, Continental drift and Phanerozoic carbonate accumulation in shallow-shelf and deep-marine settings: Journal of Geology, v. 110, p. 75-87, doi: $10.1086 / 324318$.

Walter, L. M., and Burton, E. A., 1990, Dissolution of recent platform carbonate sediments in marine pore fluids: American Journal of Science, v. 290, p. 601-643.

Walter, L. M., and Morse, J. W., 1984, Magnesian calcite stabilities: A reevaluation: Geochimica et Cosmochimica Acta, v. 48, p. 1059-1069, doi: 10.1016/0016-7037(84)90196-0.

Walter, L. M., Bishop, S. A., Patterson, W. P., Lyons, T. W., O’Nions, R. K., Gruszczynski, M., Sellwood, B. W. and Coleman, M. L., 1993, Dissolution and recrystallization in modern carbonates: evidence from pore water and solid phase chemistry: Philosophical Transactions of the Royal Society London A, v. 344, n. 1670, p. 27-36, doi: 10.1098/rsta.1993.0072.

Walter, L. M., Ku, T. C. W., Muehlenbachs, K., Patterson, W. P., and Bonnell, L., 2007, Controls on the $\delta^{13} \mathrm{C}$ of dissolved inorganic carbon in marine pore waters: An integrated case study of isotope exchange during syndepositional recrystallization of biogenic carbonate sediments (South Florida Platform, USA): Deep-Sea Research Part II, v. 54, p. 1163-1200, doi: 10.1016/j.dsr2.2007.04.014.

Wright, V. P., and Cherns, L., 2004, Are there "black holes" in carbonate deposystems?: Geologica Acta, v. 2, p. 285-290.

Yates, K. K., and Halley, R. B., 2006, Diurnal rates of calcification and carbonate sediment dissolution in Florida Bay: Estuaries and Coasts, v. 29, p. 24-39, doi: 10.1007/BF02784696.

Zeebe, R. E., and Wolf-Gladrow, D., 2001, $\mathrm{CO}_{2}$ in Seawater: Equilibrium, Kinetics and Isotopes: The Netherlands, Elsevier Oceanography Series, v. 65,360 p. 